\title{
Oxidative repression of NHE1 gene expression involves iron-mediated caspase activity
}

\author{
AP Kumar ${ }^{1,6}$, MKX Chang ${ }^{2,6}$, L Fliegel ${ }^{3}$, S Pervaiz ${ }^{4,5}$ and M-V Clément ${ }^{\star 2,5}$
}

The mechanism of $\mathrm{Na}^{+} / \mathrm{H}^{+}$exchanger 1 (NHE1) gene repression upon exposure of cells to non-apoptotic concentrations of hydrogen peroxide $\left(\mathrm{H}_{2} \mathrm{O}_{2}\right)$ was investigated. We show that continuous presence of $\mathrm{H}_{2} \mathrm{O}_{2}$ was not required for inhibition of NHE1 promoter activity. However, the downregulation of NHE1 promoter activity and protein expression was abrogated by the presence of beta mercaptoethanol ( $\beta \mathrm{ME}$ ) and dithiothreitol. The pan-caspase inhibitor zVAD-fmk also blocked the effect of $\mathrm{H}_{2} \mathrm{O}_{2}$ on NHE1 promoter activity and expression, but unlike $\beta \mathrm{ME}$, caspase inhibition was ineffective in rescuing the early phase of NHE1 repression. Interestingly, the effect of caspase inhibition was observed only after $9 \mathrm{~h}$ of exposure to $\mathrm{H}_{2} \mathrm{O}_{2}$ and completely restored NHE1 promoter activity by 18-24 h. Using tetrapeptide inhibitors of a variety of caspases and siRNA-mediated gene silencing, caspases 3 and 6 were identified as mediators of $\mathrm{H}_{2} \mathrm{O}_{2}$-induced NHE1 repression, independent of initiator/amplifier caspase activation. Furthermore, incubation of cells with the iron chelator, desferioxamine, not only blocked the activities of caspases 3 and 6, but also affected NHE1 promoter and protein expression in a manner similar to ZVAD-fmk. These data show that a mild oxidative stress represses NHE1 promoter activity and expression via an early oxidation phase blocked by reducing agents, and a late phase requiring an iron-dependent increase in caspases 3 and 6 activities.

Cell Death and Differentiation (2007) 14, 1733-1746; doi:10.1038/sj.cdd.4402176; published online 15 June 2007

We have previously established that apoptotic death in tumor cells is tightly regulated by the ratio of intracellular superoxide $\left(\mathrm{O}_{2}^{-}\right)$to hydrogen peroxide $\left(\mathrm{H}_{2} \mathrm{O}_{2}\right) \cdot{ }^{1-4} \mathrm{An}$ increase in intracellular $\mathrm{O}_{2}^{-}$through its direct overproduction, ${ }^{3}$ upon exposure to anticancer drugs, ${ }^{5}$ following activation of the small GTPase Rac1, ${ }^{6}$ or through inhibiting the $\mathrm{O}_{2}^{-}$scavenger $\mathrm{Cu} / \mathrm{Zn}$ superoxide dismutase ( $\mathrm{Cu} / \mathrm{Zn} \mathrm{SOD})$, blocked apoptosis in tumor cells. Contrarily, a tilt towards $\mathrm{H}_{2} \mathrm{O}_{2}$ primed intracellular milieu for efficient apoptotic execution. ${ }^{7}$ More recently, we proposed $\mathrm{Na}^{+} / \mathrm{H}^{+}$exchanger 1 (NHE1) as a possible target involved in ROS-mediated regulation of cellular response to apoptosis. We presented evidence that intracellular $\mathrm{O}_{2}^{-}$was a signal for the activation of the NHE1 gene promoter, resulting in a significant increase in NHE1 protein expression, which correlated with resistance to apoptotic triggers. In contrast, addition of exogenous $\mathrm{H}_{2} \mathrm{O}_{2}$ inhibited NHE1 promoter activity and protein expression with a concomitant increase in cell sensitivity to death triggers. ${ }^{8}$

In mammalian cells, the NHE family consists of nine isoforms, NHE1 to NHE-9. Apart from its role as a principal regulator of $\mathrm{pHi}$ and cell volume, the ubiquitously expressed subtype NHE1 has been implicated in cell proliferation and transformation (for a review, see Putney et $a l^{9}$ ). Owing to the historical focus on gene induction, most reports on the regulation of transcription factors by oxidative stress have described the activation of stress-response genes by factors such as activator protein $1(\mathrm{AP}-1)$ or nuclear factor $\kappa \mathrm{B}$ $(\mathrm{NF}-\kappa \mathrm{B}) .{ }^{10}$ In contrast to the wealth of literature on redoxdependent activation of transcription factors, very little is known in terms of the oxidative repression of transcription machinery. ${ }^{11}$

In the present report, we investigated the signaling pathway involved in the inhibition of NHE1 promoter activity and protein expression at concentrations of $\mathrm{H}_{2} \mathrm{O}_{2}$ that did not activate cell death. We provide evidence linking mild oxidative stress to sustained inhibition of NHE1 promoter activity and protein expression by an iron-dependent activation of caspase 3 and 6 without the need for activation of initiator caspases 8 and/or 9 .

\section{Results}

$\mathrm{H}_{2} \mathrm{O}_{2}$ inhibits NHE1 promoter activity, mRNA level, and protein expression. To avoid scavenging of $\mathrm{H}_{2} \mathrm{O}_{2}$ by the presence of serum in the culture medium, rat muscle cell line L6 stably transfected with a NHE1 reporter gene vector (L6 $1.1 \mathrm{~kb}$ cells) ${ }^{12}$ was grown in $0.5 \%$ FBS-containing medium $24 \mathrm{~h}$ before exposure to increasing concentrations of $\mathrm{H}_{2} \mathrm{O}_{2}$. Whereas incubation of $\mathrm{L} 6$ cells to $150 \mu \mathrm{M} \mathrm{H} \mathrm{H}_{2} \mathrm{O}_{2}$ for $24 \mathrm{~h}$ showed clear signs of cell death, concentrations of $\mathrm{H}_{2} \mathrm{O}_{2}$ up to $50 \mu \mathrm{M}$ did not significantly affect cell viability even in the

\footnotetext{
${ }^{1}$ National University Medical Institutes, Yong Loo Lin School of Medicine, National University of Singapore, Singapore; ${ }^{2}$ Department of Biochemistry, Yong Loo Lin School of Medicine, National University of Singapore, Singapore; ${ }^{3}$ Department of Biochemistry, University of Alberta, Edmonton, Canada; ${ }^{4}$ Department of Physiology, Yong Loo Lin School of Medicine, National University of Singapore, Singapore and ${ }^{5}$ NUS Graduate School for Integrative Sciences and Engineering, National University of Singapore, Singapore

${ }^{*}$ Corresponding author: M-V Clément, The Yong Loo Lin School of Medicine Department of Biochemistry National University of Singapore 8 Medical Drive, MD7, 117 597, Singapore. Tel: (65) 6516-7985; Fax: (65) 6779-1453; E-mail: bchmvc@nus.edu.sg

${ }^{6}$ Both authors contributed equally to this work

Keywords: NHE1; hydrogen peroxide; iron; caspase 3 and 6

Abbreviations: $\mathrm{NHE1}, \mathrm{Na}+/ \mathrm{H}+$ exchanger $1 ; \beta \mathrm{ME}$, beta mercaptoethanol; DTT, dithiothreitol; $\mathrm{H}_{2} \mathrm{O}_{2}$, hydrogen peroxide

Received 23.10.06; revised 23.4.07; accepted 23.4.07; Edited by B Zhivotovsky; published online 15.6.07
} 
presence of $0.5 \%$ FBS (Figure 1a). Moreover, Figure $1 \mathrm{~b}$ and $c$ confirms that cell viability was not affected and no increase in the Sub-G1 fraction of cells could be detected above control-treated cells upon exposure to 25 or $50 \mu \mathrm{M} \mathrm{H}_{2} \mathrm{O}_{2}$ in medium containing $0.5 \%$ FBS. These results demonstrate that inhibition of NHE1 promoter activity occurs at nontoxic concentrations of $\mathrm{H}_{2} \mathrm{O}_{2}(25-50 \mu \mathrm{M})$ (Figure 2a). Note that $\mathrm{H}_{2} \mathrm{O}_{2}$ also induced NHE1 promoter inhibition if cells were

a
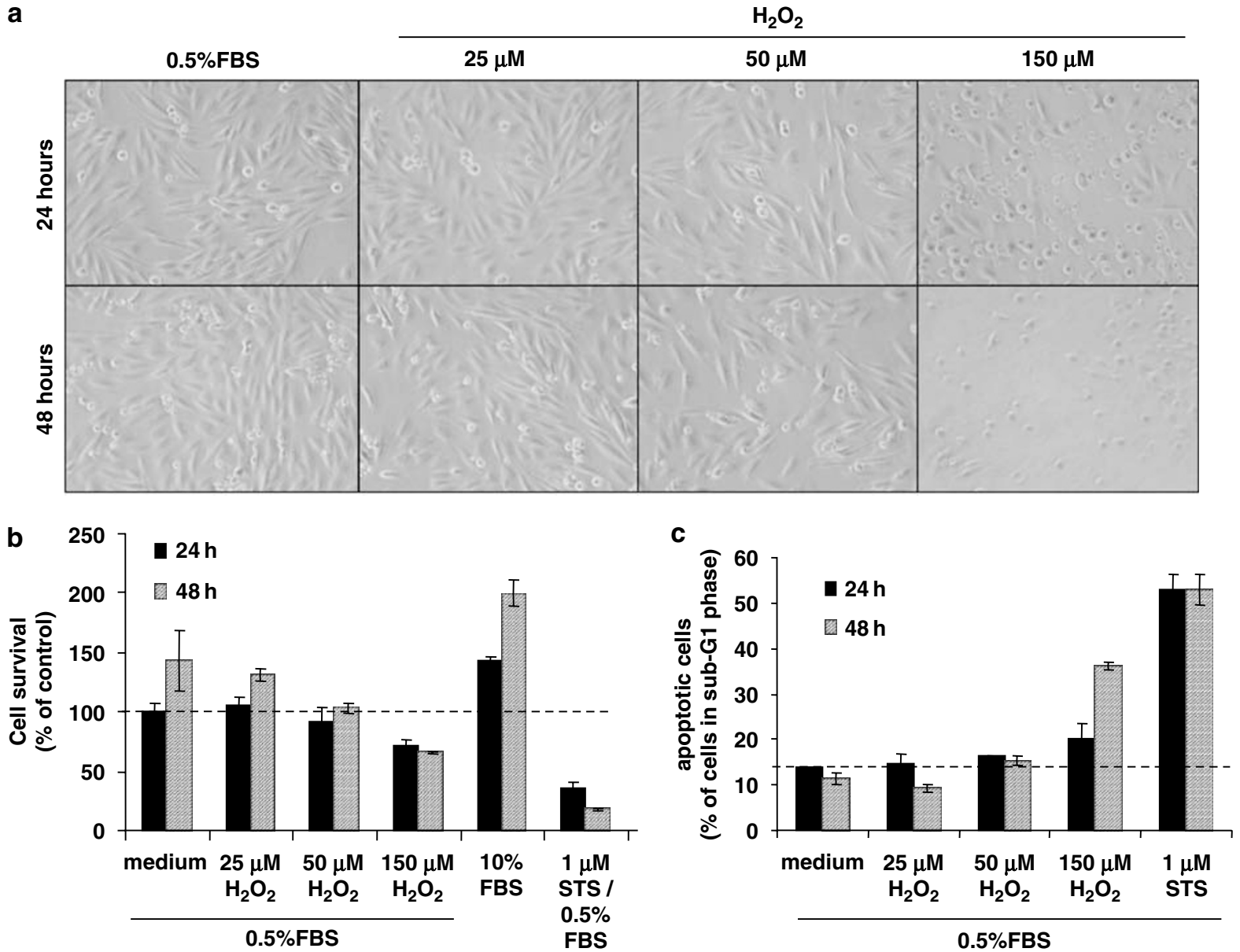

Figure 1 To determine a nontoxic $\mathrm{H}_{2} \mathrm{O}_{2}$ dose in $\mathrm{L} 6$ rat muscle cells, (a) $\mathrm{L} 61.1 \mathrm{~kb}$ cells were treated with 25,50 or $150 \mu \mathrm{M} \mathrm{H}_{2} \mathrm{O}_{2}$ in $0.5 \% \mathrm{FBS}$ for 24 or $48 \mathrm{~h}$. Photographs were taken using a digital camera attached to a light microscope ( $\mathrm{Mag} \times 200)$. (b) $\mathrm{L} 61.1 \mathrm{~kb}$ cells were treated with 25,50 or $150 \mu \mathrm{M} \mathrm{H}_{2} \mathrm{O}_{2}$ in $0.5 \% \mathrm{FBS}$ for 24 or $48 \mathrm{~h}$ or as a control cells were left in medium containing $10 \% \mathrm{FBS}$ or exposed to $1 \mu \mathrm{M}$ staurosporine (STS). Data represent the average \pm S.D. of two experiments performed in triplicate. (c) L6 $1.1 \mathrm{~kb}$ cells were treated with 25, 50,150 $\mu \mathrm{M} \mathrm{H}_{2} \mathrm{O}_{2}$, and $1 \mu \mathrm{M}$ staurosporine (STS) in $0.5 \%$ FBS for 24 or $48 \mathrm{~h}$. Single-cell suspensions of L6 $1.1 \mathrm{~kb}$ cells were prepared, stained with propidium iodide and analyzed by FACS to quantify the percent of cells with DNA content corresponding to the hypodiploid subG1 phase of the cell cycle as described in Materials and methods. Apoptotic cells was calculated by the percentage of cells in subG1 to the total cells' population. Data represent the average \pm S.D. of two experiments done in duplicate

Figure $2 \mathrm{H}_{2} \mathrm{O}_{2}$ represses NHE1 gene expression. (a) L6 $1.1 \mathrm{~kb}$ cells were incubated for $24 \mathrm{~h}$ with 25 or $50 \mu \mathrm{M}$ of $\mathrm{H}_{2} \mathrm{O}_{2}$ in medium containing $0.5 \%$ FBS before NHE1 promoter activity was assessed by luciferase assay as described in Materials and methods. Data were calculated as relative light units (RLU) per microgram total protein and expressed as percentage of the promoter activity measured in cells maintained in medium without $\mathrm{H}_{2} \mathrm{O}_{2}$ (\% of control). (b) L6 wild-type cells were transiently transfected with a $\mathrm{NHE1}$, a NF $\kappa$ B or an AP-1 reporter gene construct and a plasmid encoding for the Renilla protein before being exposed to 25 or $50 \mu \mathrm{M}$ of $\mathrm{H}_{2} \mathrm{O}_{2}$. Data were calculated as luciferase $\mathrm{RLU} / \mathrm{renilla} / \mu \mathrm{g}$ total protein and expressed as percentage of the promoter activity measured in cells maintained in medium without $\mathrm{H}_{2} \mathrm{O}_{2}$. (c) Cell lines from rat, mouse

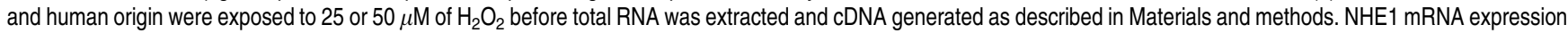
was quantified by Taqman real-time PCR, normalized to endogenous control (human GAPDH for human cell lines) and (18S RNA for mouse and rat cell lines). Relative NHE1 mRNA expression is expressed as percent of untreated control. (d) Cell lines from human (IMR90), mouse (NIH3T3) or rat (L6 $1.1 \mathrm{~kb})$ origin were exposed to different concentration of $\mathrm{H}_{2} \mathrm{O}_{2}$ for $24 \mathrm{~h}$ and Western blot analysis was performed as described in Materials and methods. NHE1 protein $(97 \mathrm{kDa})$ was detected using a mouse monoclonal antibody. Anti- $\beta$-actin $(42 \mathrm{kDa})$ was used as loading control. (b, c, d) results are represented as mean of at least three experiments carried out in duplicate \pm S.D. (e) Following $24 \mathrm{~h}$ serum deprivation in DMEM/0.5\% FBS, L6 $1.1 \mathrm{~kb}$ cells were exposed to 25 or $50 \mu \mathrm{M} \mathrm{H}_{2} \mathrm{O}_{2}$ for $3 \mathrm{~h}$ before releasing in medium containing $0.5 \% \mathrm{FBS}$ or $10 \%$ FBS without $\mathrm{H}_{2} \mathrm{O}_{2}$ for 24,48 and $72 \mathrm{~h}$. Control cells not exposed to $\mathrm{H}_{2} \mathrm{O}_{2}$ were similarly released in medium $+10 \% \mathrm{FBS}$. Promoter activity of NHE1 was assessed by luciferase assay, calculated as RLU/ $\mu \mathrm{g}$ total protein and expressed as percent of the promoter activity assessed in cells that were not exposed to $\mathrm{H}_{2} \mathrm{O}_{2}$ and left in medium containing $0.5 \%$ FBS for the same period of time. (f) $\mathrm{L} 61.1 \mathrm{~kb}$ were exposed to $50 \mu \mathrm{M} \mathrm{H}_{2} \mathrm{O}_{2}$ as described in A and cell density was assessed by crystal violet staining as described in Materials and methods and expressed as $\mathrm{OD}$ at $595 \mathrm{~nm}$. Results from $(\mathbf{e}, \mathbf{f})$ are from one representative experiment out of a minimum of three carried out in triplicate \pm S.D. 
a
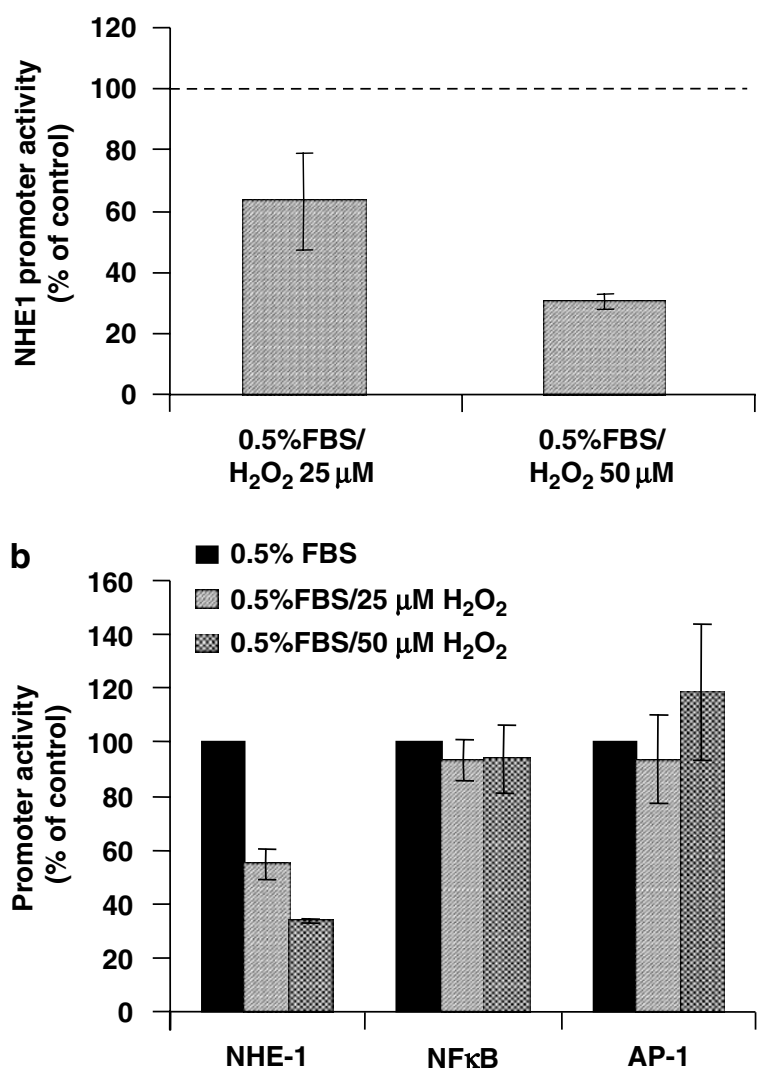

C $0.5 \%$ FBS

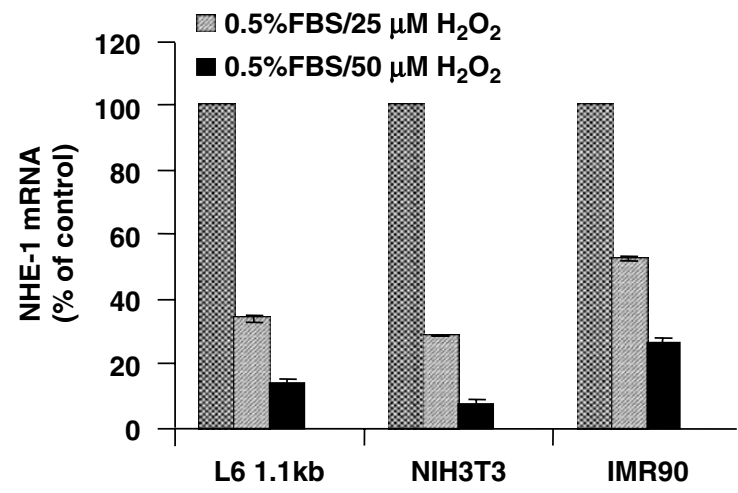

d

L6 $1.1 \mathrm{~kb}$

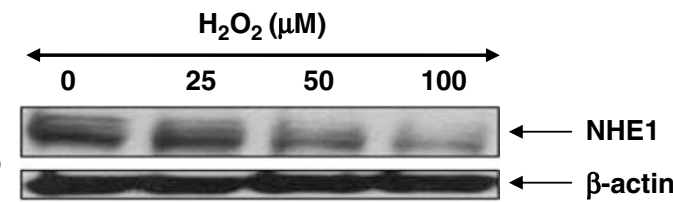

50

70

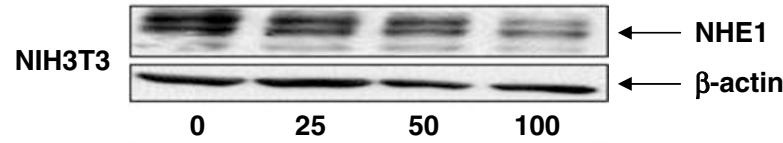

IMR90

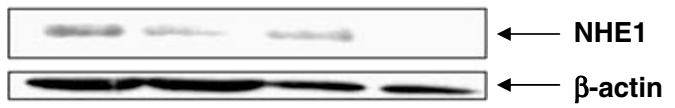

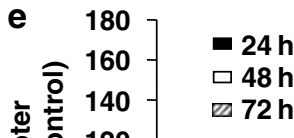

응 융 120

흥요 80

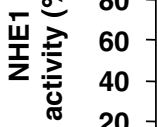

0
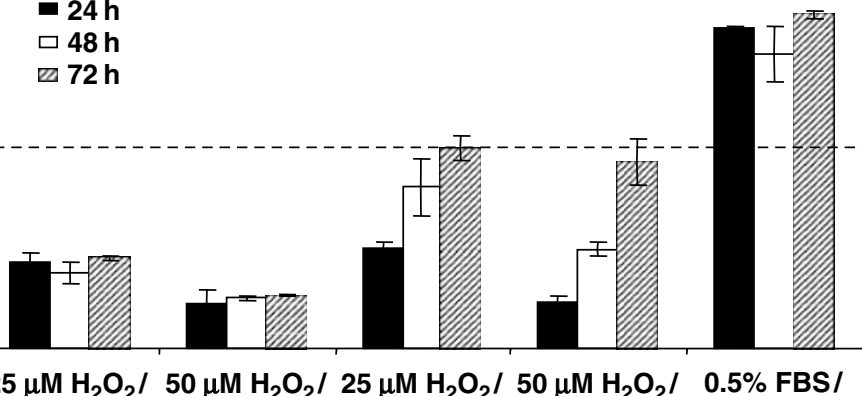

$25 \mu \mathrm{M} \mathrm{H}_{2} \mathrm{O}_{2} / 50 \mu \mathrm{M} \mathrm{H}_{2} \mathrm{O}_{2} / 25 \mu \mathrm{M} \mathrm{H}_{2} \mathrm{O}_{2} / 50 \mu \mathrm{M} \mathrm{H}_{2} \mathrm{O}_{2} / 0.5 \%$ FBS $/$

$0.5 \%$ FBS

$0.5 \%$ FBS

$10 \%$ FBS

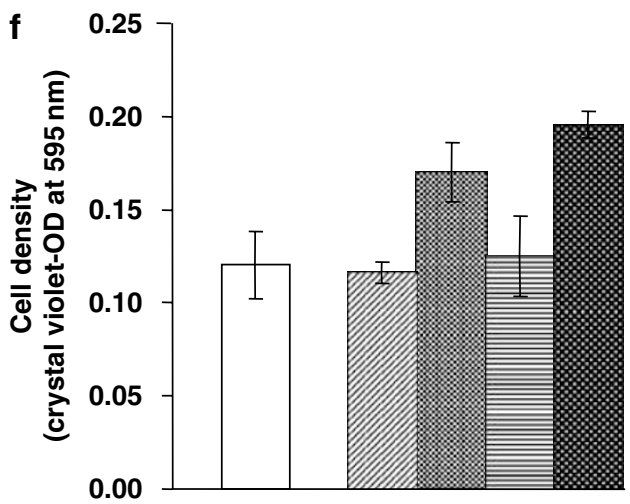

$\square \mathrm{H}_{2} \mathrm{O}_{2}$

ख $\mathrm{H}_{2} \mathrm{O}_{2}+24$ hours $0.5 \%$ FBS

国 $\mathrm{H}_{2} \mathrm{O}_{2}+24$ hours $10 \%$ FBS

目 $\mathrm{H}_{2} \mathrm{O}_{2}+48$ hours $0.5 \%$ FBS

$\mathrm{H}_{2} \mathrm{O}_{2}+48$ hours $10 \%$ FBS 
grown in medium with $10 \%$ FBS; however, the concentration of $\mathrm{H}_{2} \mathrm{O}_{2}$ to obtain an inhibitory effect similar to that in $0.5 \%$ FBS had to be doubled (data not shown). To quell any doubts that the inhibitory effect of $\mathrm{H}_{2} \mathrm{O}_{2}$ on NHE1 promoter activity could be an artifact due to the stable integration of the reporter gene in L6 $1.1 \mathrm{~kb}$ cells' genome or that the inhibition of $\mathrm{NHE} 1$ promoter activity by $\mathrm{H}_{2} \mathrm{O}_{2}$ was nonspecific, parental L6 cells were transiently transfected with either a $1.1 \mathrm{~kb}$ $\mathrm{NHE} 1$, an NF- $\kappa \mathrm{B}$, or an $\mathrm{AP}-1$ reporter gene construct before exposure to 25 or $50 \mu \mathrm{M} \mathrm{H}_{2} \mathrm{O}_{2}$ for $24 \mathrm{~h}$. Results showed that the effect of $\mathrm{H}_{2} \mathrm{O}_{2}$ was not a nonspecific function of transcription shut down, but a selective effect of $\mathrm{H}_{2} \mathrm{O}_{2}$ on $\mathrm{NHE} 1$ promoter activity, whereas NF- $\kappa \mathrm{B}$ and $\mathrm{AP}-1$ promoter activities were not affected (Figure 2b). Furthermore, realtime PCR analysis of NHE1 mRNA level and Western blot analysis of NHE1 protein expression, following incubation of the cells with increasing concentration of $\mathrm{H}_{2} \mathrm{O}_{2}$ for $24 \mathrm{~h}$ confirmed that inhibition of NHE1 promoter activity led to inhibition of NHE1 transcription and protein expression in a variety of cell lines (Figure $2 c$ and $d$ ).

\section{$\mathrm{H}_{2} \mathrm{O}_{2}$ initiates the signal for NHE1 promoter repression. According to the conventional dogma, exogenously added $\mathrm{H}_{2} \mathrm{O}_{2}$ is consumed by respiring cells and hence rapidly dissipates from the extracellular medium. Consistent with this notion, exogenously added $\mathrm{H}_{2} \mathrm{O}_{2}$ to $\mathrm{L} 6$ $1.1 \mathrm{~kb}$ cells in medium containing $0.5 \%$ FBS was consumed within $3 \mathrm{~h}$, whereas in the same medium without cells and over the same period of time, there was no substantial decrease in $\mathrm{H}_{2} \mathrm{O}_{2}$ concentration (data not shown). These data prompted us to question if maximal inhibition of NHE1 promoter activity could be achieved without the need for continuous presence of $\mathrm{H}_{2} \mathrm{O}_{2}$ (a minimum $3 \mathrm{~h}$ exposure). $\mathrm{L} 6$ $1.1 \mathrm{~kb}$ cells were incubated with $50 \mu \mathrm{M} \mathrm{H}_{2} \mathrm{O}_{2}$ for a minimum of $5 \mathrm{~min}$ to a maximum of $3 \mathrm{~h}$ before the culture medium was replaced with the control medium (without $\mathrm{H}_{2} \mathrm{O}_{2}$ ) for a total incubation period of $24 \mathrm{~h}$ at which time point the activity of the promoter was assessed. Results showed that $3 \mathrm{~h}$ exposure to $\mathrm{H}_{2} \mathrm{O}_{2}$ was enough to achieve the level of inhibition of NHE1 promoter activity similar to that obtained upon continuous exposure to $\mathrm{H}_{2} \mathrm{O}_{2}$ for $24 \mathrm{~h}$ (data not shown). Hence, to minimize the production of toxic metabolites due to the continuous presence of $\mathrm{H}_{2} \mathrm{O}_{2}$ in the culture medium, in all subsequent experiments, cells were exposed to $\mathrm{H}_{2} \mathrm{O}_{2}$ for $3 \mathrm{~h}$ followed by the release of cells in fresh culture medium for the remaining duration of the experiment. Interestingly,}

repression of NHE1 promoter activity measured at $24 \mathrm{~h}$ was sustained for as long as $72 \mathrm{~h}$ without further decrease in NHE1 promoter activity or loss of cell viability in cells maintained in $0.5 \%$ FBS. However, release of cells in culture medium containing $10 \%$ FBS following the initial exposure to $\mathrm{H}_{2} \mathrm{O}_{2}$ did not completely prevent the inhibition of the promoter activity, but allowed the promoter activity to recover to the level of cells grown in 10\% FBS (without exposure to $\mathrm{H}_{2} \mathrm{O}_{2}$ ) within $72 \mathrm{~h}$ (Figure 2e and f). In addition, the recovery of NHE1 promoter activity correlated with the capacity of the cells to proliferate again (Figure 2f).

Oxidation is involved in the initiation but not the sustained inhibition of NHE1 promoter activity by $\mathbf{H}_{\mathbf{2}} \mathbf{O}_{2}$. To test if oxidation was part of the signaling pathway involved in the repression of NHE1 promoter activity by $\mathrm{H}_{2} \mathrm{O}_{2}$, L6 $1.1 \mathrm{~kb}$ cells were pre-incubated for $2 \mathrm{~h}$ with or without $500 \mu \mathrm{M}$ beta mercaptoethanol $(\beta \mathrm{ME})$ or $500 \mu \mathrm{M}$ dithiothreitol (DTT) before exposure to $25 \mu \mathrm{M}$ or $50 \mu \mathrm{M} \mathrm{H} \mathrm{H}_{2} \mathrm{O}_{2}$. $\quad \beta \mathrm{Me}$ and DTT inhibited $\mathrm{H}_{2} \mathrm{O}_{2}$-mediated repression of NHE1 promoter activity and protein expression (Figure $3 a$ and $b$ ). To provide further support to oxidant-induced repression of NHE1 promoter activity, L6 $1.1 \mathrm{~kb}$ cells were treated with a commonly used thiol oxidant, diamide. Within $24 \mathrm{~h}$ of incubation with diamide, NHE1 promoter activity was significantly inhibited with a resultant decrease in NHE1 protein expression by $48 \mathrm{~h}$ (Figure $3 \mathrm{c}$ and d). The continuous presence of diamide for $48 \mathrm{~h}$ did not induce cell death as shown by the absence of an increase in the percentage of cells in the sub-G1 phase (Figure $3 e$ ), but was necessary to obtain a decrease in NHE1 protein expression compared to exposure to $\mathrm{H}_{2} \mathrm{O}_{2}$ for only $3 \mathrm{~h}$ (and followed up for a total duration of $24 \mathrm{~h}$ in normal feeding medium). These results probably reflect the difference in the efficiency of diamide compared to $\mathrm{H}_{2} \mathrm{O}_{2}$ to inhibit $\mathrm{NHE} 1$ promoter activity. A comparison of the inhibitory effect of diamide and $\mathrm{H}_{2} \mathrm{O}_{2}$ on $\mathrm{NHE} 1$ promoter activity revealed a striking similarity for the early part of the incubation $(5 \mathrm{~h}$ exposure to diamide versus $3 \mathrm{~h}$ initial exposure to $\mathrm{H}_{2} \mathrm{O}_{2}$ followed by $2 \mathrm{~h}$ in normal feeding medium); however, a follow-up of the cells for up to $24 \mathrm{~h}$ after the initial $3 \mathrm{~h}$ exposure to $\mathrm{H}_{2} \mathrm{O}_{2}$ showed a significantly stronger inhibition of NHE1 promoter activity than treatment for $24 \mathrm{~h}$ with diamide (Figure 3c). Hence, we next evaluated if blocking oxidation would prevent the effect of the initial exposure $(3 \mathrm{~h})$ to $\mathrm{H}_{2} \mathrm{O}_{2}$ on NHE1 promoter activity. Interestingly, $\beta \mathrm{ME}$ was effective

Figure $3 \quad \mathrm{H}_{2} \mathrm{O}_{2}$-induced inhibition of NHE1 promoter activity is rescued by reducing agents. (a) Cells were pre-incubated with $500 \mu \mathrm{M} \mathrm{DTT}$ or $500 \mu \mathrm{M} \beta \mathrm{ME}$ in DMEM/0.5\% FBS for $2 \mathrm{~h}$ before being exposed to $50 \mu \mathrm{M} \mathrm{H}_{2} \mathrm{O}_{2}$ for a further $3 \mathrm{~h}$. The medium was then replaced with fresh $\beta$ ME or DTT in DMEM/0.5\% FBS for another $24 \mathrm{~h}$ before NHE 1 promoter activity (RLU/ $\mu \mathrm{g}$ total protein) was assessed as described in Materials and methods. (b) L6 $1.1 \mathrm{~kb}$ cells were treated with $50 \mu \mathrm{M} \mathrm{H}_{2} \mathrm{O}_{2}$ with or without $2 \mathrm{~h}$ preincubation with $\beta \mathrm{ME}$ before $\mathrm{H}_{2} \mathrm{O}_{2}$ treatment. Cells were harvested $24 \mathrm{~h}$ after $\mathrm{H}_{2} \mathrm{O}_{2}$ treatment. Fifty microgram of total cell lysates were subjected to Western Blot analysis for NHE1 expression. (c) Following $24 \mathrm{~h}$ serum deprivation in DMEM/0.5\% FBS, medium was replaced with fresh DMEM/0.5\% FBS. Cells were then exposed to $50 \mu \mathrm{M} \mathrm{H} \mathrm{H}_{2}$ or $100 \mu \mathrm{M}$ diamide for various durations before NHE1 promoter activity was assessed by luciferase assay (RLU/ $\mu \mathrm{g}$ total protein) as described in Materials and methods. Results are expressed as percent of untreated cells (\% of control). (d) Expression of NHE1 protein was assessed as described in (c). (e) L6 $1.1 \mathrm{~kb}$ cells were treated with $100 \mu \mathrm{M}$ diamide in $0.5 \%$ FBS for 24 or $48 \mathrm{~h}$. Single-cell suspensions of L6 $1.1 \mathrm{~kb}$ cells were prepared, stained with propidium iodide and analyzed by FACS to quantify the percent of cells with DNA content corresponding to the hypodiploid subG1 phase of the cell cycle. Percent of apoptotic cells was calculated by the percentage of cells in subG1 to the total cells' population. Data represent the average \pm S.D. of two experiments carried out in duplicate. (f) Following $24 \mathrm{~h}$ serum deprivation in DMEM/0.5\% FBS, medium was replaced with fresh DMEM/0.5\% FBS. L61.1 kb cells were then treated with $50 \mu \mathrm{M} \mathrm{H}_{2} \mathrm{O}_{2}$ and $500 \mu \mathrm{M} \beta \mathrm{ME}$ added to the cells at different time intervals (i.e. -2 represents $\beta \mathrm{ME}$ added $2 \mathrm{~h}$ before $\mathrm{H}_{2} \mathrm{O}_{2}$ challenge and so on). In all cases, $\mathrm{H}_{2} \mathrm{O}_{2}$ was added for $3 \mathrm{~h}$, medium was then replaced and cells were harvested at the end of $24 \mathrm{~h}$ post- $\mathrm{H}_{2} \mathrm{O}_{2}$ challenge. Inhibition of NHE1 promoter activity by $\mathrm{H}_{2} \mathrm{O}_{2}$ is shown on the extreme right of the graph as a positive control. NHE1 promoter activity is expressed as RLU/ $\mu \mathrm{g}$ total protein 
in blocking the effect of $\mathrm{H}_{2} \mathrm{O}_{2}$ only if added $2 \mathrm{~h}$ before or within $5 \mathrm{~h}$ after (maximum) exposure to $\mathrm{H}_{2} \mathrm{O}_{2}$ (Figure $3 \mathrm{f}$ ).

Caspases are involved in the sustained inhibition of NHE1 gene expression by $\mathbf{H}_{\mathbf{2}} \mathbf{O}_{2}$. Next, we evaluated the involvement of the caspase family of cysteine proteases, usually associated with apoptotic cell death signaling. However, of late, the involvement of caspase proteases in physiological settings such as embryonal development, cell proliferation, and post-translational regulation of transcription factors, has been documented. ${ }^{13}$ L6 $1.1 \mathrm{~kb}$ cells were exposed to $50 \mu \mathrm{M} \mathrm{H}_{2} \mathrm{O}_{2}$ in the presence or absence of the pan-caspase inhibitor, z-VAD-fmk $(100 \mu \mathrm{M})$. The presence of z-VAD-fmk strongly blocked the inhibitory effect of $\mathrm{H}_{2} \mathrm{O}_{2}$ on NHE1 promoter activity and NHE1 protein expression (Figure $4 \mathrm{a}$ and $\mathrm{b}$ ). In addition, the pan-caspase inhibitor prevented

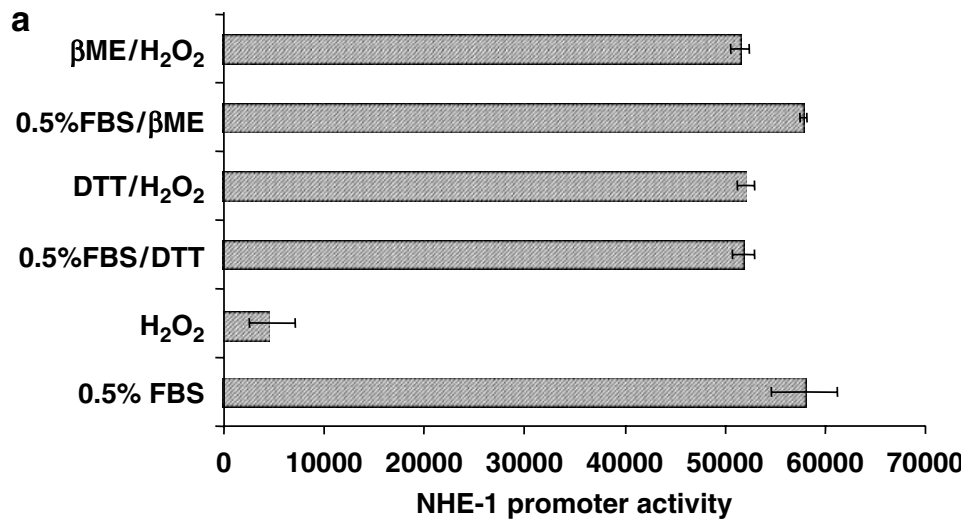

b
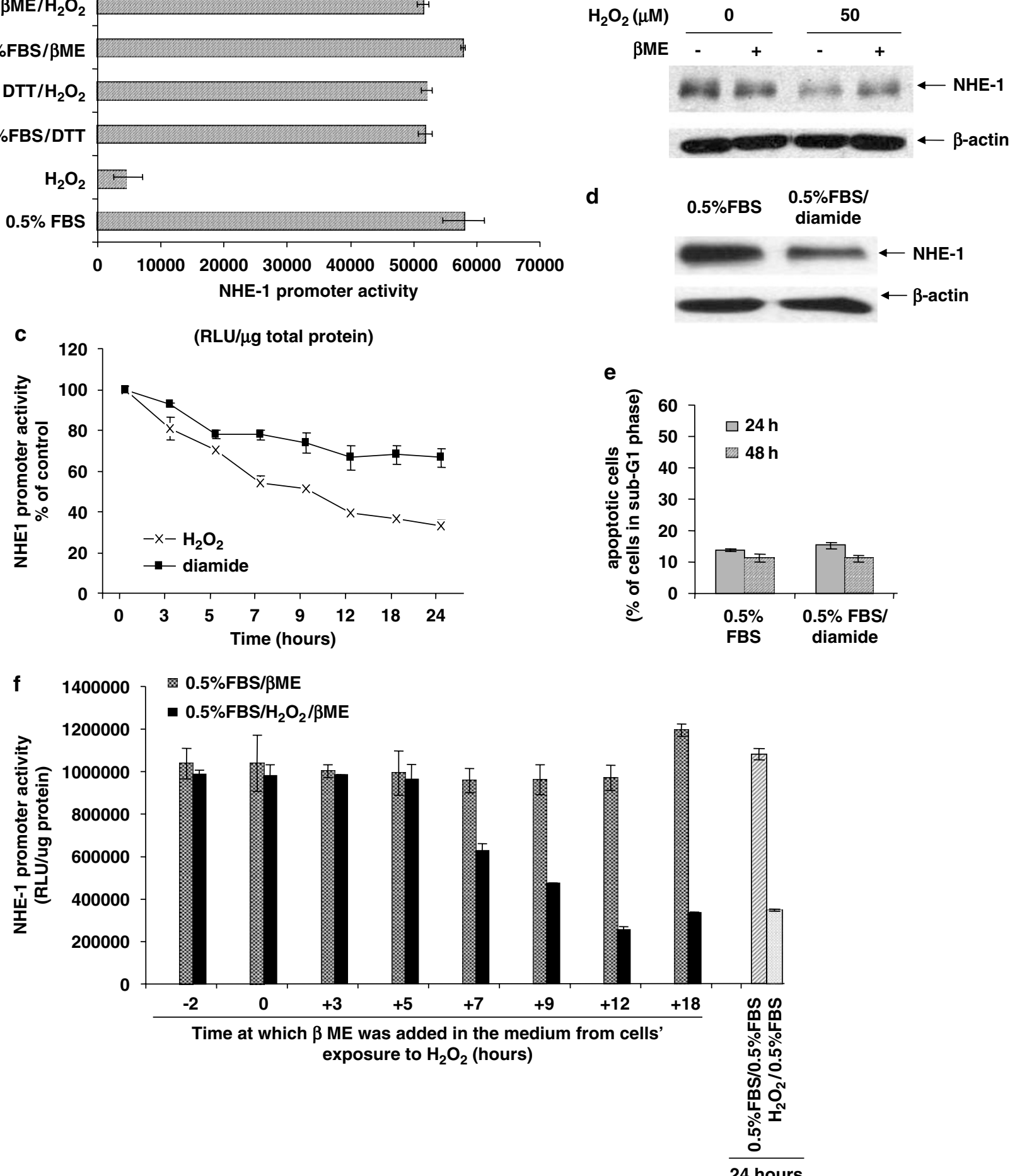

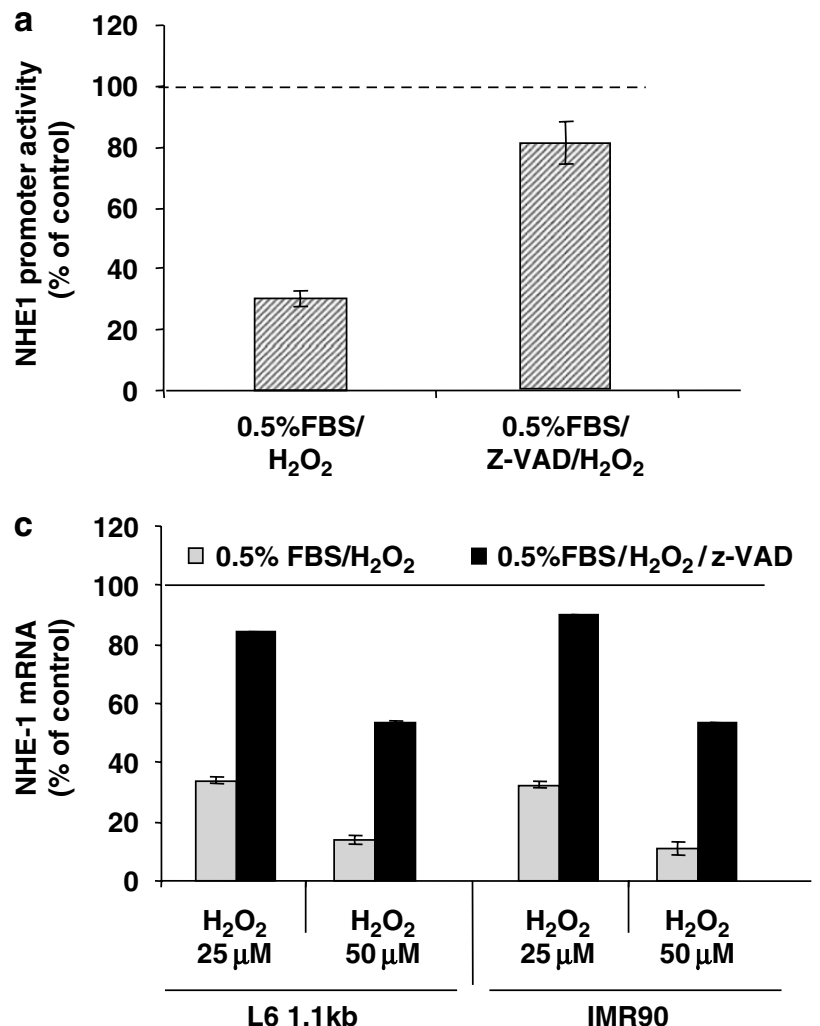

b
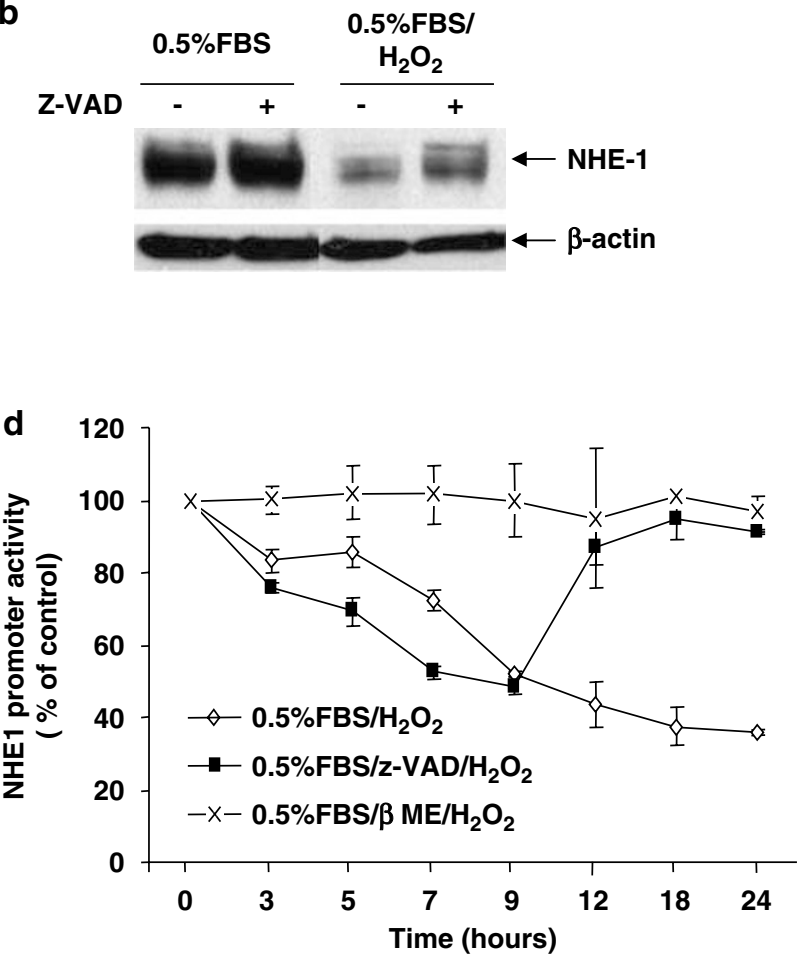

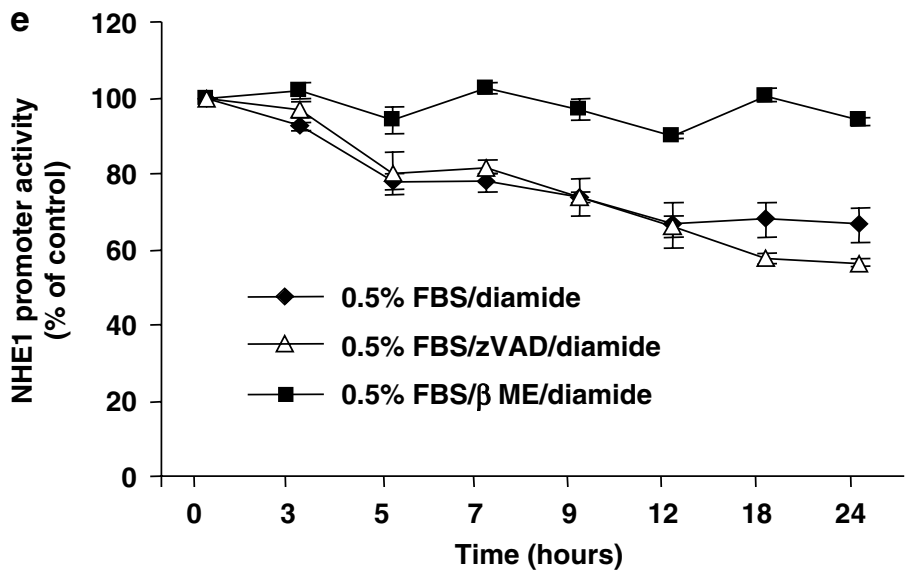

Figure 4 zVAD-fmk prevents $\mathrm{H}_{2} \mathrm{O}_{2}$-induced inhibition of NHE1 promoter activity. (a) Following $24 \mathrm{~h}$ serum deprivation in DMEM/0.5\% FBS, L6 $1.1 \mathrm{~kb}$ cells were preincubated for $2 \mathrm{~h}$ with $100 \mu \mathrm{M}$ zVAD-fmk in DMEM/0.5\% FBS, before exposure to $50 \mu \mathrm{M} \mathrm{H}_{2} \mathrm{O}_{2}$ for $3 \mathrm{~h}$. Cells were harvested $24 \mathrm{~h}$ following treatment with $\mathrm{H}_{2} \mathrm{O}_{2}$ for luciferase assay. NHE1 promoter activity was calculated as RLU/ $\mu$ g total protein and expressed as percent of untreated control cells. (b) Expression of NHE1 was assessed by Western blotting described in Materials and methods. A representative blot from two independent experiments is shown. (c) NHE1 mRNA levels were quantitated by Taqman real-time PCR, normalized to endogenous control (18S RNA for $\mathrm{L} 61.1 \mathrm{~kb}$ and human GAPDH for IMR90 cell lines). Relative NHE1 mRNA expression is shown as percent of non- $\mathrm{H}_{2} \mathrm{O}_{2}$ treated controls with or without ZVAD-fmk. (d) Cells were pre-incubated for $2 \mathrm{~h}$ in the absence or presence of $100 \mu \mathrm{M} \mathrm{zVAD-fmk}$ or $500 \mu \mathrm{M} \beta \mathrm{ME}$ in DMEM/0.5\% FBS and exposed to $50 \mu \mathrm{M} \mathrm{H}_{2} \mathrm{O}_{2}$ for $3 \mathrm{~h}$. Cells were then released in DMEM/0.5\% without $\mathrm{H}_{2} \mathrm{O}_{2}$, but containing either zVAD-fmk or $\beta M E$. NHE1 promoter activity was calculated at the indicated times as RLU/ $\mu \mathrm{g}$ total protein and expressed as percent of non- $\mathrm{H}_{2} \mathrm{O}_{2}$-treated controls. (e) Following $24 \mathrm{~h}$ serum deprivation in DMEM/0.5\% FBS, cells were preincubated as in (d), and exposed to $100 \mu \mathrm{M}$ diamide. NHE1 promoter activity was assessed by luciferase assay at the indicated times as RLU/ $\mu \mathrm{g}$ total protein and expressed as percent of respective non-diamide treated controls. Results shown are average out of three experiments carried out in triplicate \pm S.D.

$\mathrm{H}_{2} \mathrm{O}_{2}$-induced inhibition of NHE1 gene transcription assessed by real-time PCR not only in L6 $1.1 \mathrm{~kb}$ cells, but also in the human cell line IMR90 (Figure 4c).

To further decipher the effect(s) of oxidation and caspase activation in the regulation of NHE1 gene expression, a time kinetic analysis of $\mathrm{H}_{2} \mathrm{O}_{2}$-mediated repression of $\mathrm{NHE1}$ promoter activity in the presence or absence of $\beta \mathrm{ME}$ or z-VAD-fmk was performed. NHE1 promoter activity decreased in a time-dependent manner (up to $24 \mathrm{~h}$ ) following initial $3 \mathrm{~h}$ exposure of $\mathrm{L} 61.1 \mathrm{~kb}$ cells to $\mathrm{H}_{2} \mathrm{O}_{2}$; however, 
pre-incubation of cells for $2 \mathrm{~h}$ with $\beta \mathrm{ME}$ completely abolished the inhibitory effect of $\mathrm{H}_{2} \mathrm{O}_{2}$ on $\mathrm{NHE} 1$ promoter activity (Figure 4d). On the contrary, the caspase inhibitor, z-VADfmk, did not affect the initial decrease in NHE1 promoter activity for up to $9 \mathrm{~h}$ from exposure to $\mathrm{H}_{2} \mathrm{O}_{2}$; however, z-VADfmk rescued NHE1 promoter activity to its basal level, 18 to $24 \mathrm{~h}$ after exposure of cells to $\mathrm{H}_{2} \mathrm{O}_{2}$ (Figure $4 \mathrm{~d}$ ). The necessity for a mechanism dependent on caspase activation, but independent of oxidation, to maintain $\mathrm{H}_{2} \mathrm{O}_{2}$-induced inhibition of NHE1 promoter activity is further supported by data that z-VAD had no effect on diamide-mediated inhibition of NHE1 promoter activity, whereas the presence of $\beta \mathrm{ME}$ completely prevented it (Figure 4e).

Caspases 3 and 6 are involved in $\mathrm{H}_{2} \mathrm{O}_{2}$-induced inhibition of NHE1 promoter activity. Next, we set out to identify the caspase(s) involved in this pathway. Therefore, time kinetic analyses of $\mathrm{H}_{2} \mathrm{O}_{2}$-mediated repression of $\mathrm{NHE} 1$ promoter activity were performed in the presence or absence of the tetrapeptide inhibitor of caspase-8 (z-IETD-fmk), caspase-9 (z-LEHD-fmk), caspase 6 (z-VEID-fmk), or caspase-3 (z-DEVD-fmk). Whereas the inhibitor of caspase 8 or 9 had no effect on $\mathrm{H}_{2} \mathrm{O}_{2}$-induced downregulation of NHE1 promoter activity, inhibition of caspase 3 or 6 rescued the promoter activity to its basal level from $9 \mathrm{~h}$ onward following the initial exposure to $\mathrm{H}_{2} \mathrm{O}_{2}$ (Figure 5a). Moreover, similar to the results obtained with the tetrapeptide inhibitors, gene silencing of caspase 3 or 6 allowed NHE1 promoter activity to recover from the initial inhibition induced by $\mathrm{H}_{2} \mathrm{O}_{2}$ (Figure 5b). In addition, the enzymatic activities of caspases 3 and 6 were induced in cells incubated with $\mathrm{H}_{2} \mathrm{O}_{2}$; neither caspase 8 nor caspase 9 were significantly active (Figure 5c).

Caspase-dependent inhibition of NHE1 promoter activity is only partially responsible for the decrease in NHE1 protein expression. During apoptotic cell death, activation of caspase 3 has been shown to cleave a wide spectrum of protein substrates, including NHE1. ${ }^{14}$ Hence, despite the convincing evidence implicating $\mathrm{H}_{2} \mathrm{O}_{2}$-mediated caspase 3 and 6 activation in the inhibition of NHE1 promoter activity, we questioned if the downregulation of NHE1 protein detected upon exposure to $\mathrm{H}_{2} \mathrm{O}_{2}$ was only a result of the inhibition of NHE1 transcription. L6 $1.1 \mathrm{~kb}$ cells were incubated with either $50 \mu \mathrm{M} \mathrm{H}_{2} \mathrm{O}_{2}$ or $1 \mu \mathrm{g} / \mathrm{ml}$ actinomycin $\mathrm{D}$ (ACT.D) in the presence or absence of Z-VAD and the levels of NHE1 mRNA and NHE1 protein were assessed after $24 \mathrm{~h}$ of treatment. Addition of z-VAD with ACT.D appeared to be necessary as ACT.D alone was able to activate caspase 3 similar to that obtained with $\mathrm{H}_{2} \mathrm{O}_{2}$ (Figure 6a). Hence, the decrease in NHE1 protein in the presence of ACT.D alone could not only be due to a decrease in transcription, but also by way of direct cleavage of NHE1 by caspase 3 . In the presence of $z-V A D$, cells exposed to ACT.D for $24 \mathrm{~h}$ underwent a $67 \%$ decrease in NHE1 mRNA compared to control cells (Figure 6b). This decrease in NHE1 mRNA corresponded to a $23 \%$ reduction in protein expression $(n=4)$ (Figure 6c). The decrease in NHE1 transcription upon exposure to $50 \mu \mathrm{M} \mathrm{H}_{2} \mathrm{O}_{2}$ was comparable to that obtained with $\mathrm{zVAD}+\mathrm{ACT} . \mathrm{D}$ and the inhibitory effect on protein expression was only slightly more pronounced than the combined treatment with zVAD and ACT.D (Figure $6 \mathrm{c}$ and d). These data indicate that the major effect of $\mathrm{H}_{2} \mathrm{O}_{2}$ on NHE1 protein expression could be accounted for by the inhibitory effect on NHE1 gene transcription (mRNA); however, the possible involvement of post-transcriptional events such as caspase 3-mediated cleavage of the protein cannot be completely ruled out at this point (Figure 6e).

$\mathrm{H}_{2} \mathrm{O}_{2}$-mediated activation of caspases 3 and 6 involves the intermediacy of iron. Under conditions that mimic in vivo situation, the oxidative event that triggers apoptosis and the consequent activation of caspases by $\mathrm{H}_{2} \mathrm{O}_{2}$ has been shown to involve Fenton-type chemistry. ${ }^{15}$ The two main consequences of a Fenton reaction are production of hydroxyl radical $(\mathrm{OH})$ and redox cycling of iron. Hence, to assess if $\mathrm{OH}^{-}$and/or iron were involved in the caspasedependent inhibition of $\mathrm{NHE} 1$ promoter activity by $\mathrm{H}_{2} \mathrm{O}_{2}$, time kinetic analyses of $\mathrm{H}_{2} \mathrm{O}_{2}$-mediated repression of $\mathrm{NHE} 1$ promoter activity were performed in the presence of either the $\mathrm{OH}^{\prime}$ scavenger, sodium formate $(\mathrm{HCOONa})$, or the iron chelator, DFO. Whereas, the HCOONa had no significant effect on $\mathrm{H}_{2} \mathrm{O}_{2}$-induced repression of $\mathrm{NHE} 1$ promoter activity, the effect of iron chelation mirror-imaged the effect of caspase inhibition on NHE1 promoter activity and in response to $\mathrm{H}_{2} \mathrm{O}_{2}$ (Figure 7a). This was further corroborated by Western blot analysis of NHE1 protein expression; DFO blocked the downregulation of $\mathrm{NHE} 1$ by $\mathrm{H}_{2} \mathrm{O}_{2}$, whereas HCOONa had no effect (Figure $7 \mathrm{~b}$ and $\mathrm{c}$ ). In addition, prior incubation of $\mathrm{L} 61.1 \mathrm{~kb}$ cells with DFO inhibited $\mathrm{H}_{2} \mathrm{O}_{2}$-induced activities of caspases 3 and 6 (Figure $7 d$ and e).

To provide further impetus to these findings linking iron to $\mathrm{H}_{2} \mathrm{O}_{2}$-mediated activation of caspases 3 and 6 , we assessed the effect of direct exposure of $\mathrm{L} 61.1 \mathrm{~kb}$ cells to $\mathrm{FeCl}_{3}$. The effect of $\mathrm{FeCl}_{3}$ on $\mathrm{NHE} 1$ promoter activity and protein expression was similar to that of $\mathrm{H}_{2} \mathrm{O}_{2}$ (Figure $8 \mathrm{a}$ and $b$ ). Furthermore, the repression of $\mathrm{NHE} 1$ promoter by $\mathrm{FeCl}_{3}$ was unaffected by the presence of the $\mathrm{OH}^{\cdot}$ scavenger $\mathrm{HCOONa}$ (Figure 8c), but could be rescued by the tetrapeptide inhibitors of caspases 3 and 6 or by small interfering RNA (siRNA) gene silencing of these two caspases (Figure $8 d$ and e). Note that some increase in the percentage of cells in sub-G1 was detected in the presence of $\mathrm{FeCl}_{3}$ compared to cells left in the control medium (Figure 8f). However, this is not surprising as iron is critical in many aspect of cell survival.

A region of the NHE1 promoter containing an AP-2binding site is necessary to induce the inhibition of the NHE1 promoter by $\mathrm{H}_{\mathbf{2}} \mathrm{O}_{2}$. Finally, to further explore the molecular basis for $\mathrm{H}_{2} \mathrm{O}_{2}$-mediated inhibition of $\mathrm{NHE} 1$ promoter activity, wild-type L6 cells were transiently transfected with various $5^{\prime}$ deletion constructs of the $1.1 \mathrm{~kb}$ promoter before being treated with $\mathrm{H}_{2} \mathrm{O}_{2}$. The region responsive to the inhibition by $\mathrm{H}_{2} \mathrm{O}_{2}$ contains a ' $G \mathrm{GCN} \mathrm{N}_{4} \mathrm{GGG}$ ' sequence shown to be the sequence for the binding site of an AP-2 or AP-2-like transcription factor in the NHE1 promoter ${ }^{16}$ (Figure 9a). Indeed, mutation or removal of that region in the promoter abolished the inhibitory effect of $\mathrm{H}_{2} \mathrm{O}_{2}$ (Figure 9a). Interestingly, when similar experiment was carried out with deletion mutants of the human NHE1 
a

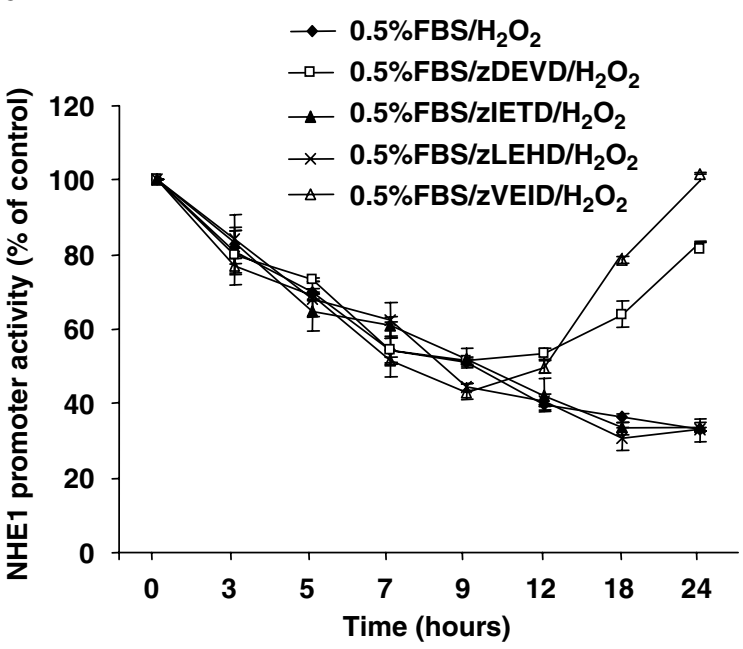

b

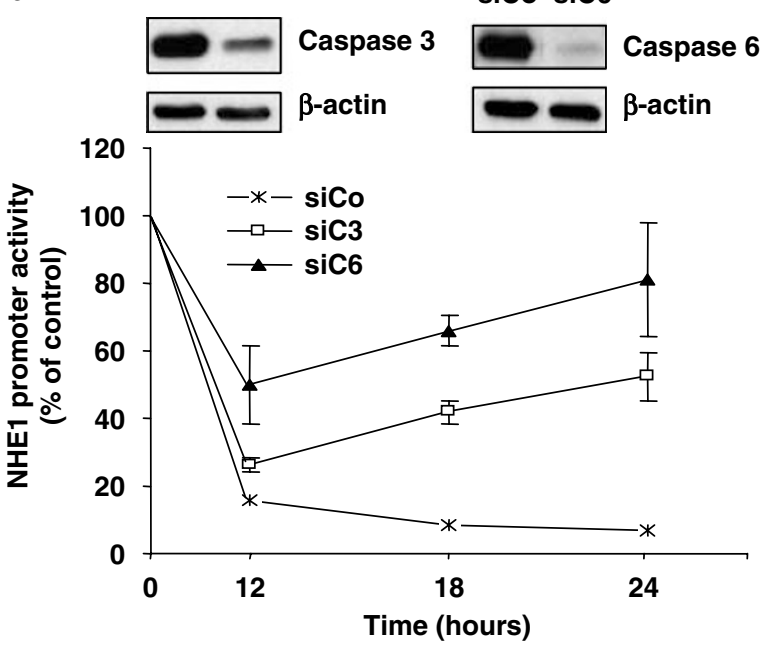

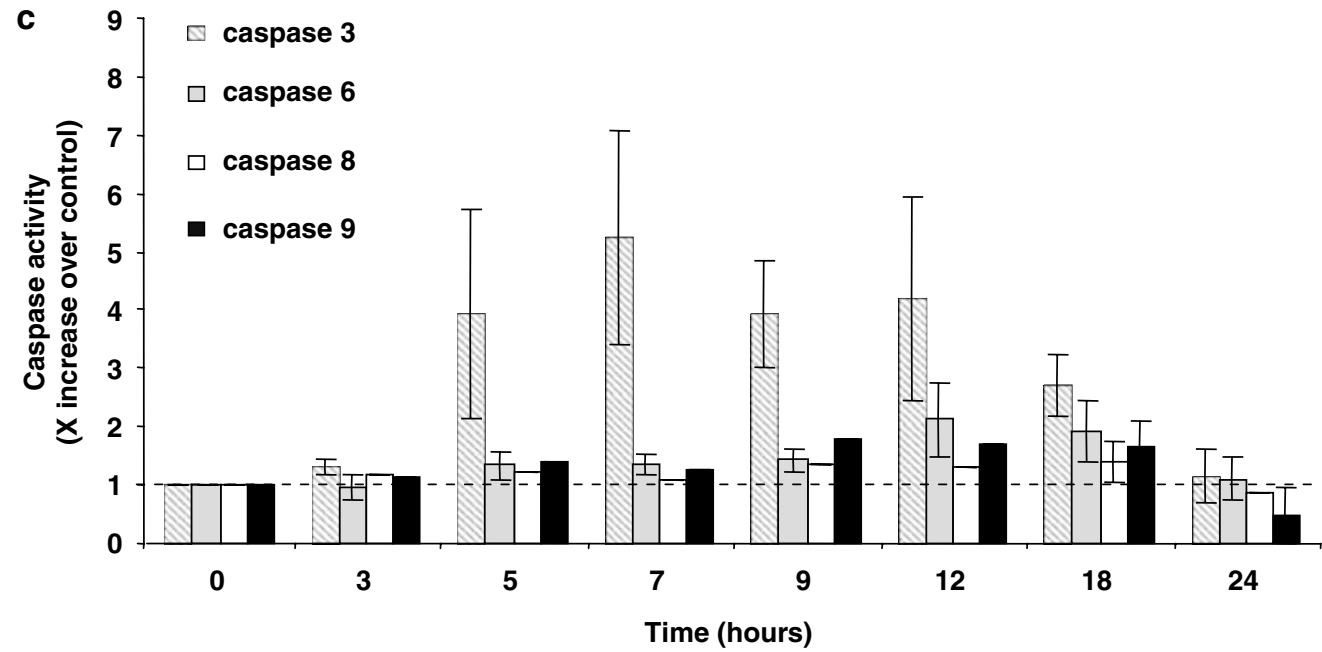

Figure $5 \quad \mathrm{H}_{2} \mathrm{O}_{2}$-induced inhibition of NHE1 promoter activity involves activation of caspases 3 and 6 . (a) Following $24 \mathrm{~h}$ serum deprivation in DMEM/0.5\% FBS, L6 $1.1 \mathrm{~kb}$ cells were pre-incubated in fresh DMEM/0.5\% FBS with $30 \mu \mathrm{M}$ caspase 3 (zDEVD), caspase 8 (zIETD), caspase 9 (zLEHD) or caspase 6 (zVEID) inhibitors before exposure to $50 \mu \mathrm{M} \mathrm{H}_{2} \mathrm{O}_{2}$. NHE1 promoter activity was calculated as RLU/ $\mu \mathrm{g}$ total protein and expressed as percent of untreated control cells. (b) $\mathrm{L} 61.1 \mathrm{~kb}$ cells were transfected with either a control siRNA (siCo) or specific siRNA to caspase 3 (siC3) or caspase 6 (siC6). Fourty hours post-transfection, cells were exposed to $25 \mu \mathrm{M} \mathrm{H}_{2} \mathrm{O}_{2}$ for $3 \mathrm{~h}$ before being harvested for luciferase assay to measure NHE1 promoter activity at 12,18 and $24 \mathrm{~h}$ post- $\mathrm{H}_{2} \mathrm{O}_{2}$ treatment. NHE1 promoter activity was calculated as in (a). Total cell lysates were subjected to Western blot analysis for detecting caspases 3 and 6 as in Materials and methods. (c) Total cell extracts from L6 $1.1 \mathrm{~kb}$ cells following $50 \mu \mathrm{M} \mathrm{H} \mathrm{O}_{2}$ treatment at varying time intervals were collected and assayed for the activities of caspases 8, 9,6 and 3 as described in Materials and methods. Caspase activity was normalized to protein concentration and expressed as fold increase over untreated cells ( $\times$ increase over control). Data shown are mean of three experiments carried out in duplicate \pm S.D.

promoter, a region containing the same AP-2-binding sequence was also found to be responsible for the inhibition of the promoter activity by $\mathrm{H}_{2} \mathrm{O}_{2}$ (Figure $9 b$ ).

\section{Discussion}

In the present study, we provide evidence that $\mathrm{H}_{2} \mathrm{O}_{2}$ is a signaling molecule that induces repression of $\mathrm{NHE}_{1}$ gene transcription leading to a decrease in NHE1 protein expression. The data support a bi-phasic signaling response to a short exposure to $\mathrm{H}_{2} \mathrm{O}_{2}$ involving an oxidation-dependent rapid initial phase followed by an iron-mediated caspasedependent sustained inhibition of NHE1 promoter activity and gene expression.
Thiol oxidation of an NHE1-specific transcription factor is responsible for the initial inhibition of NHE1 gene expression upon exposure to $\mathrm{H}_{2} \mathrm{O}_{2}$. There are several signaling mechanisms that could account for the effect of the initial but reversible $\mathrm{H}_{2} \mathrm{O}_{2}$-mediated repression of $\mathrm{NHE} 1$ promoter activity. In addition to the oxidation of redoxsensitive residues on the transcription factor(s) involved in NHE1 gene expression, oxidative conditions can also activate kinase/phosphatase cascade and modify the phosphorylation status or target amino acids of NHE1specific transcription factors. However, in the present study, the observations that reducing agents such as $\beta \mathrm{Me}$ or DTT prevented $\mathrm{H}_{2} \mathrm{O}_{2}$-mediated initial inhibition of NHE1 promoter activity, and that the thiol oxidizing agent diamide 


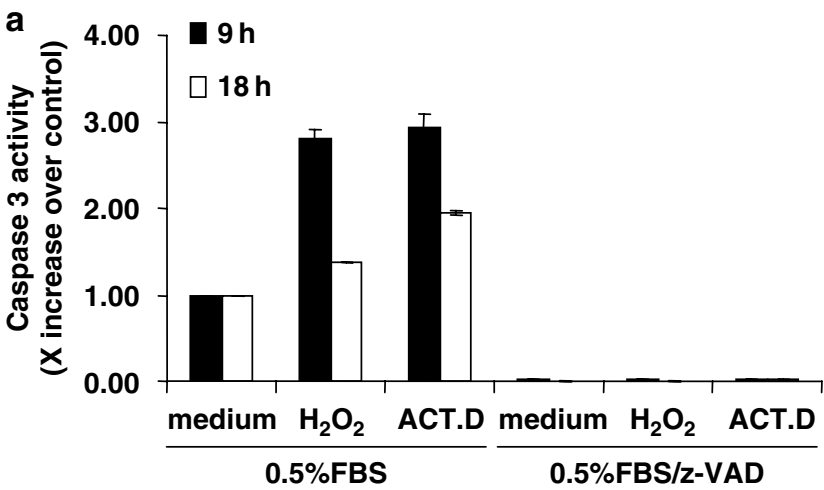

C

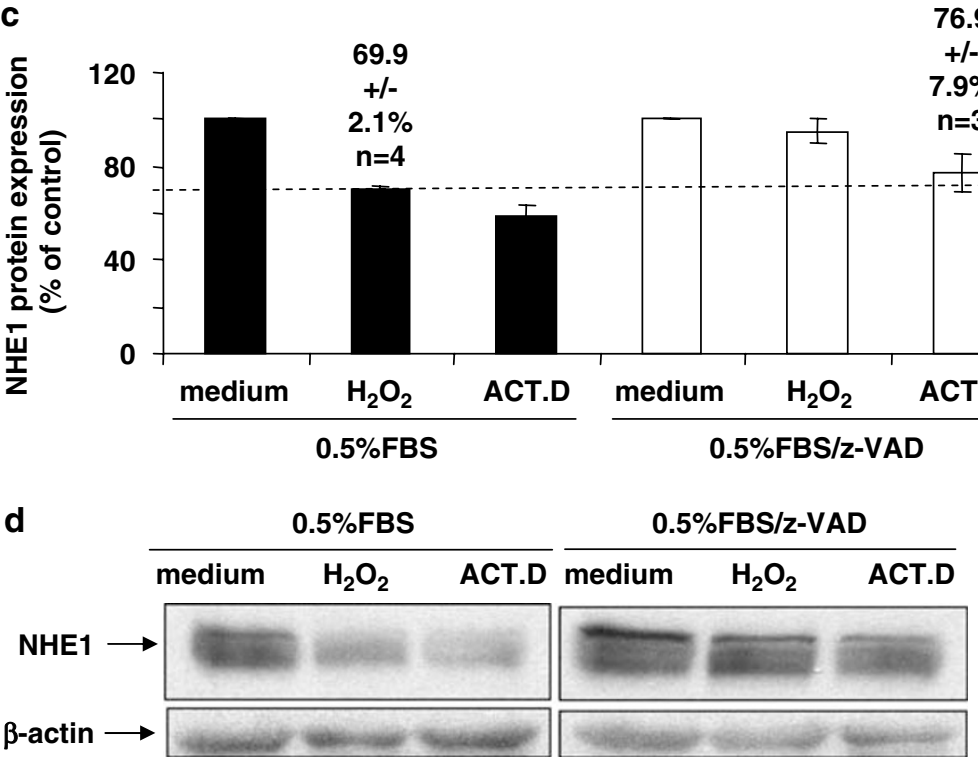

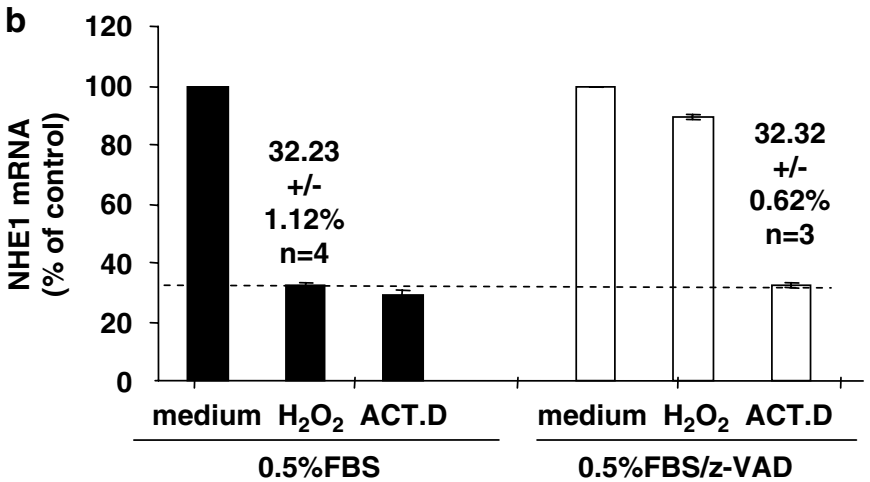

$0.5 \%$ FBS

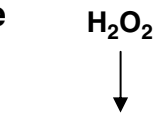

Activation of Caspase 3/6

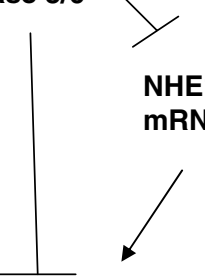

NHE1 Protein expression 24 hours after exposure to $\mathrm{H}_{2} \mathrm{O}_{2}$

Figure 6 Downregulation of NHE1 protein with $\mathrm{H}_{2} \mathrm{O}_{2}$ is largely transcriptional. (a) Total cell extracts from L6 $1.1 \mathrm{~kb}$ cells following either $50 \mu \mathrm{M} \mathrm{H} \mathrm{H}_{2}$ or $1 \mu \mathrm{g} / \mathrm{ml} \mathrm{ACT}$.D treatment in the absence and presence of $100 \mu \mathrm{M} z-V A D$ at 9 and $18 \mathrm{~h}$ time intervals were collected and assayed for the caspase-3 activity as described in Materials and methods. Caspase activity was normalized to protein concentration and expressed as fold increase over untreated cells $(x$ increase over control). Data shown are the mean of three experiments carried out in duplicate \pm S.D. (b) In the same experimental set-up as (a), total RNA was collected. NHE1 mRNA expression was quantified by Taqman realtime PCR, normalized to endogenous control (18S RNA). Relative NHE1 mRNA expression is expressed as percent of untreated control. (c) NHE1 protein expression from the same experimental set-up as (a, b) performed by Western blotting and quantitated by densometric analysis. NHE1 protein expression is shown as percent decrease from untreated controls (\% of control). Data shown are the mean of four independent experiments \pm S.D. (d) A representative blot for NHE1 expression in (c) is shown. (e) Summary diagram showing NHE1 transcriptional and post-transcriptional contribution to the total decrease in NHE1 protein, when L6 $1.1 \mathrm{~kb}$ cells were treated with $50 \mu \mathrm{M}$ $\mathrm{H}_{2} \mathrm{O}_{2}$

mimicked the effect of $\mathrm{H}_{2} \mathrm{O}_{2}$ strongly suggest that the likely mechanism for the initial inhibition of the promoter activity involves the oxidation of thiol moiety of cysteine that may be present in the transcription factor(s) necessary for NHE1 expression. Interestingly, Dyck et al. ${ }^{17}$ have shown a key role for a transcription factor from the AP-2 family in the regulation of NHE1 gene transcription. The AP-2 transcription factor family is a set of developmentally regulated, retinoic acid inducible genes composed of: AP- $2 \alpha$, AP $-2 \beta$, AP $-2 \gamma, \mathrm{AP}-2 \delta$, and AP- $2 \varepsilon .{ }^{18}$ Oxidation of recombinant AP- $2 \alpha$ protein with $\mathrm{H}_{2} \mathrm{O}_{2}$ has been shown to inhibit its DNA-binding activity to synthetic AP-2oligodeoxynucleotides. Furthermore, the diminished DNA-binding activity of AP-2, following diamide or $\mathrm{H}_{2} \mathrm{O}_{2}$ pre-treatment, could be restored by the addition of DTT or $\beta$-ME. ${ }^{19}$ Analysis of the promoter region involved in the downregulation of NHE1 promoter activity by $\mathrm{H}_{2} \mathrm{O}_{2}$, revealed that in the mouse as well as in the human promoter the presence of a region with an AP-2-binding site was necessary for the inhibition. These data suggest that thiol oxidation of an AP-2 or an AP-2-like transcription factor could be responsible for the initial inhibition of NHE1 gene expression upon incubation with $\mathrm{H}_{2} \mathrm{O}_{2}$.

Activation of caspases 3 and 6 are responsible for the oxidative repression of NHE1 expression. Caspase activation, in particular caspase 3 , is mainly linked to the execution of cell death via cleavage of a wide variety of substrates involved in the maintenance of cell survival. ${ }^{20}$ Similarly, caspase-dependent cleavage of transcription factors is observed in cells undergoing apoptosis, and caspase-mediated inhibition of gene transcription is linked 
a

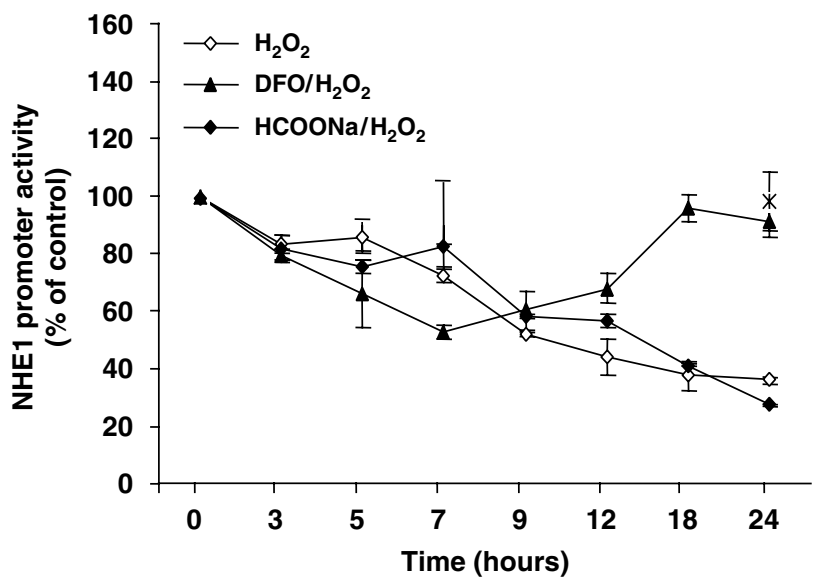

b

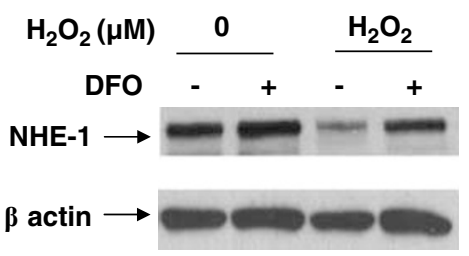

C

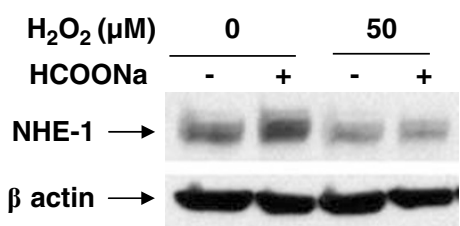

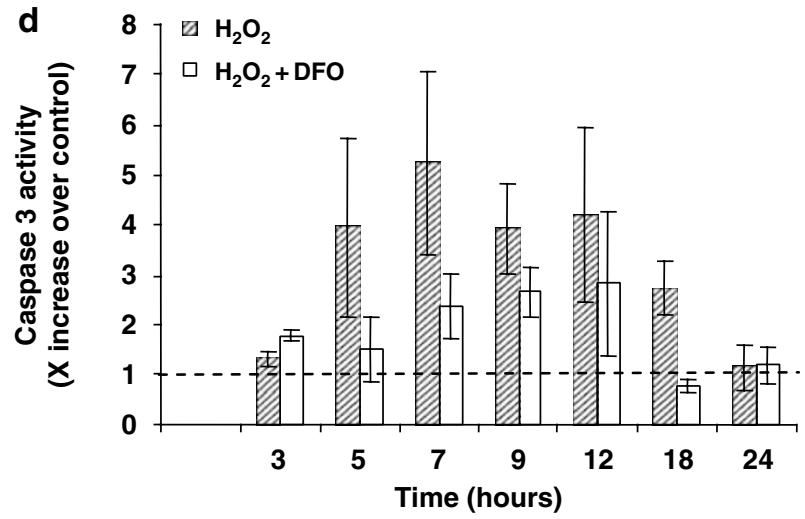

e

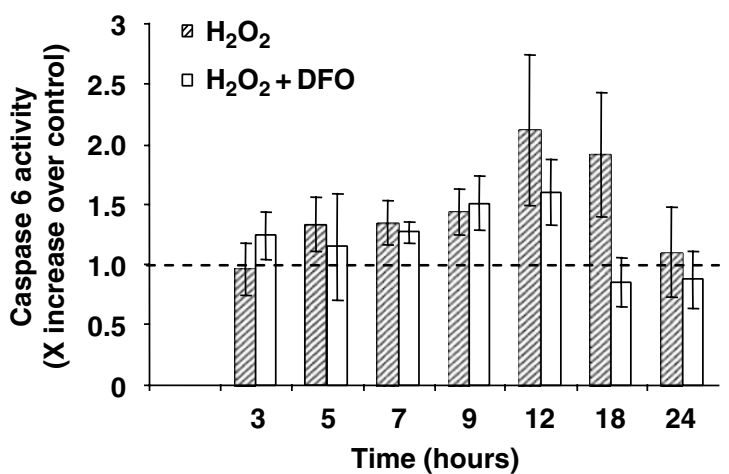

Figure 7 Intermediacy of Iron in caspases 3 and 6 mediated inhibition of NHE1 promoter activity by $\mathrm{H}_{2} \mathrm{O}_{2}$. (a) Following $24 \mathrm{~h}$ serum deprivation in DMEM/0.5\% FBS, cells were pre-treated for $2 \mathrm{~h}$ in fresh DMEM/0.5\% FBS with or without $1 \mathrm{mM} \mathrm{DFO}$ or $20 \mathrm{mM} \mathrm{HCOONa}$, before the addition of $50 \mu \mathrm{M} \mathrm{H}_{2} \mathrm{O}_{2}$ for $3 \mathrm{~h}$. Cells were released in DMEM/ $0.5 \% \mathrm{FBS}$ containing either DFO or $\mathrm{HCOONa}$, but without $\mathrm{H}_{2} \mathrm{O}_{2}$. NHE1 promoter activity was assessed by luciferase assay (RLU/ $\mu \mathrm{g}$ total protein) and expressed as percent of non- $\mathrm{H}_{2} \mathrm{O}_{2}$-treated controls at the indicated time points with or without DFO or HCOONa. Expression of NHE1 was assessed with $50 \mu \mathrm{M} \mathrm{H} \mathrm{H}_{2} \mathrm{O}_{2}$ in the absence or presence of $1 \mathrm{mM} \mathrm{DFO}$ (b), or $20 \mathrm{mM} \mathrm{HCOONa}$ (c) by Western blotting described in Materials and methods. A representative blot from two independent experiments is shown. Total cell extracts from L6 $1.1 \mathrm{~kb}$ cells following $50 \mu \mathrm{M} \mathrm{H}_{2} \mathrm{O}_{2}$ treatment in the absence and presence of $1 \mathrm{mM}$ DFO were assayed for the caspase 3 (d) and caspase 6 (e) activities as described in Materials and methods. Caspase activities were normalized to protein concentration and expressed as fold increase over untreated cells $(\times$ increase over control). Results from (a-e) are mean of at least three experiments carried out in duplicate \pm S.D.

to the repression of survival proteins. Direct targeting of transcription factors has also been shown as a mechanism of caspase-dependent gene silencing. ${ }^{21,22}$ Here, we show a new role for active caspases 3 and 6 in the absence of cell death, that is, the sustained repression of protein expression upon mild oxidative stress. In the absence of caspase activation, a mild oxidative stress only induces a rapid but reversible inhibition of NHE1 promoter activity that is not sufficient to influence NHE1 protein levels. However, $\mathrm{H}_{2} \mathrm{O}_{2}-$ mediated activation of caspases 3 and 6 appears to maintain the repression initiated by the mild oxidative stress. These results provide evidence that aside from their role in the execution of apoptotic cell death, activation of caspases 3 and 6 could be an alternative mechanism involved in the oxidative repression of gene transcription. Hence, it is plausible that in addition to being sensitive to oxidation, NHE1-specific transcription factors are substrates of caspase 3 and/or 6 . To that end, members of the AP-2 family proteins, involved in basal expression of NHE1, have been shown to be substrates for caspases 3 and $6 .^{23}$
The physiological relevance of such a sustained oxidative repression of $\mathrm{NHE} 1$ could be that during chronic mild oxidative stress, NHE1 transcription factor may be subject to oxidation as well as depletion due to sustained activation of caspases 3 and 6. This could lead to a long-term decrease in NHE1 expression without the need for constant production of ROS. Chronic decrease in NHE1 levels could impair cell growth through accumulation in the G2/M phase of the cell cycle ${ }^{9}$ or induce acidification of the intracellular milieu. ${ }^{8}$ To that regard, exposure of $\mathrm{L} 61.1 \mathrm{~kb}$ cells to nontoxic concentrations of $\mathrm{H}_{2} \mathrm{O}_{2}$ induced cell growth arrest; however, the growth arrest was reversible along with the reactivation of NHE1 promoter upon incubation of the cells in medium containing 10\% FBS following incubation with $\mathrm{H}_{2} \mathrm{O}_{2}$.

Iron-dependent activation of caspases 3 and 6 is responsible for the sustained repression of NHE1 expression by $\mathrm{H}_{2} \mathrm{O}_{2}$. Presence of the reducing agents $\beta$ ME or DTT, at the time of cells' exposure to $\mathrm{H}_{2} \mathrm{O}_{2}$, not only prevented the initial inhibition of NHE1 promoter activity, but 


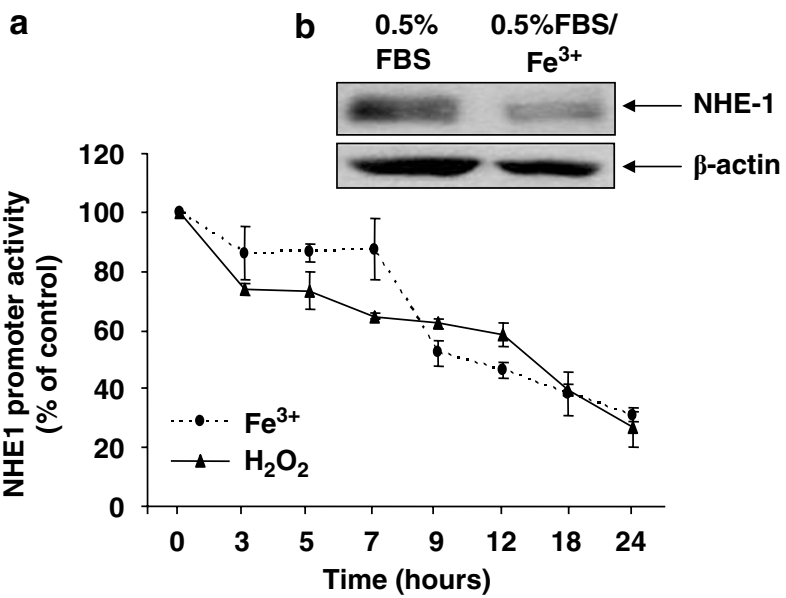

C
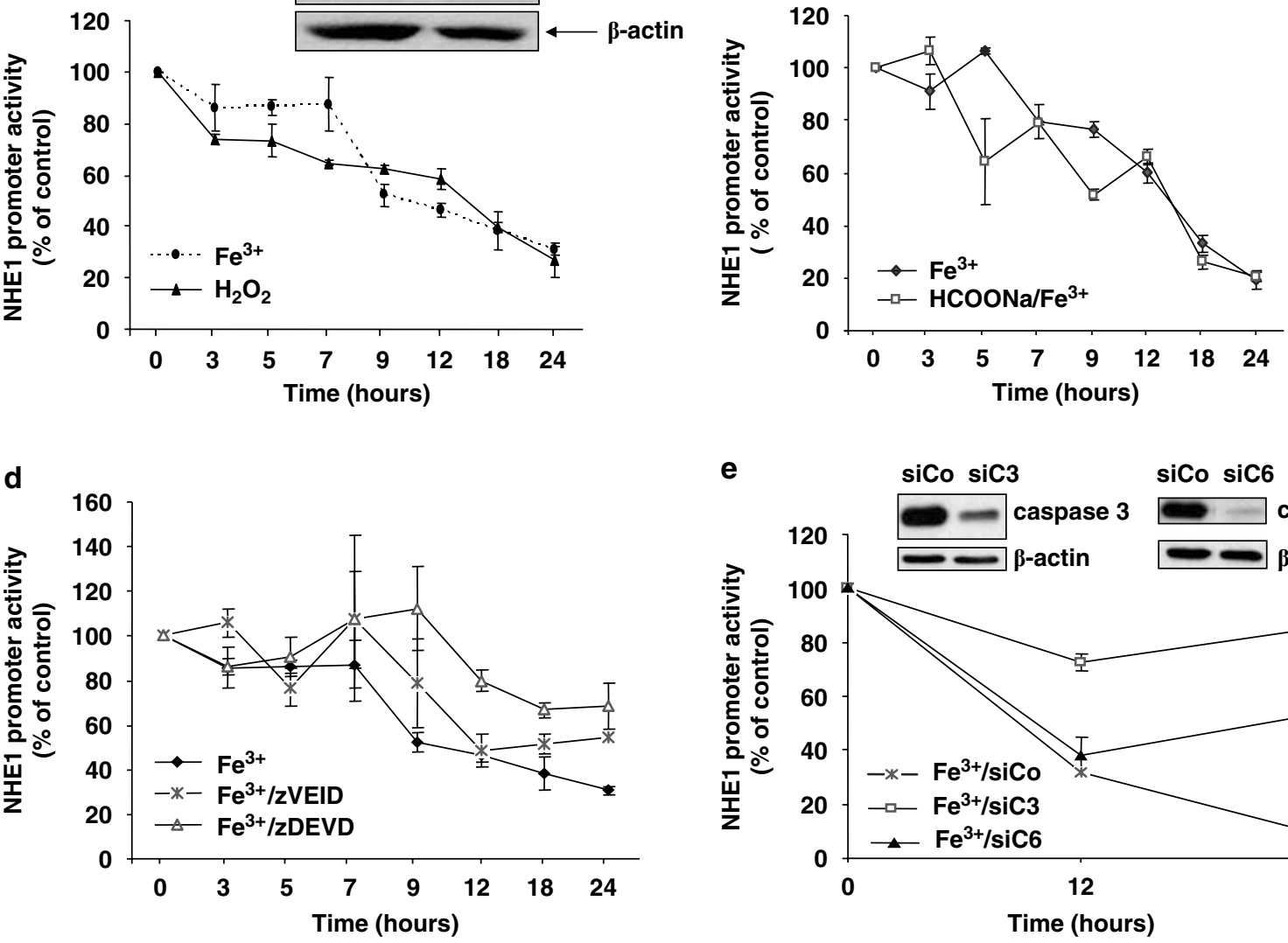

e siCo sic3 siCo sic6
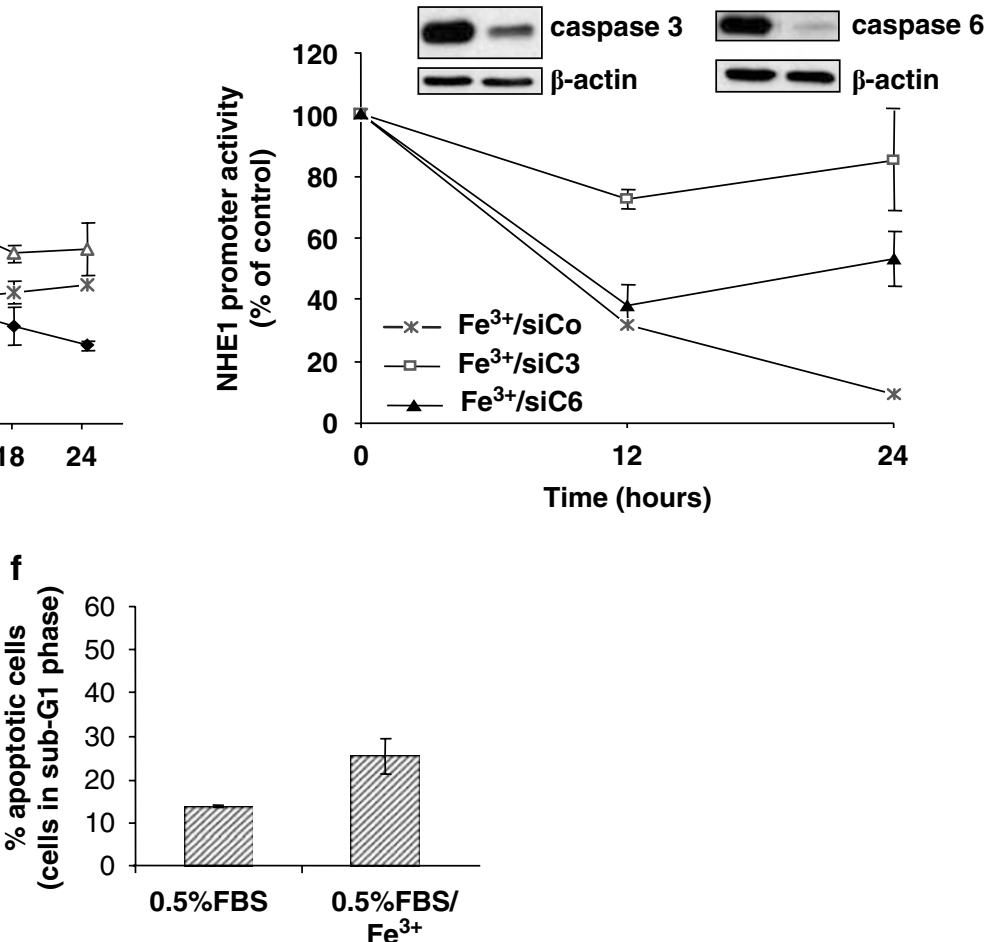

Figure 8 Activities of caspases 3 and 6 are required for $\mathrm{FeCl}_{3}$-induced NHE1 promoter inhibition. (a) Following $24 \mathrm{~h}$ serum deprivation in DMEM/0.5\% FBS, cells were exposed to $500 \mu \mathrm{M} \mathrm{FeCl}_{3}$ or $50 \mu \mathrm{M} \mathrm{H}_{2} \mathrm{O}_{2}$ in fresh DMEM/0.5\% FBS. Luciferase activity was measured at the indicated time points and NHE1 promoter activity was calculated as RLU/ $\mu \mathrm{g}$ total protein and expressed as percent of untreated cells. (b) Expression of NHE1 following $500 \mu \mathrm{M} \mathrm{FeCl}$ was assessed by Western blotting as described in Materials and methods. (c) Following $24 \mathrm{~h}$ serum deprivation in DMEM/0.5\% FBS, cells were exposed to $500 \mu \mathrm{M} \mathrm{FeCl}$ with and without $2 \mathrm{~h} \mathrm{HCOONa} \mathrm{pre-incubation} \mathrm{in} \mathrm{fresh}$ DMEM/0.5\% FBS. Luciferase activity was measured at the indicated time points and NHE1 promoter activity was calculated as RLU/ $\mu$ g total protein and expressed as percent of untreated cells. (d) Following $24 \mathrm{~h}$ serum deprivation in DMEM/0.5\% FBS, cells were pre-incubated for $2 \mathrm{~h}$ in fresh DMEM/0.5\% FBS with $30 \mu \mathrm{M}$ zDEVD or zVEID, and then treated with $500 \mu \mathrm{M} \mathrm{FeCl}_{3}$. NHE1 promoter activity was determined by luciferase assay and calculated as RLU/ $\mu \mathrm{g}$ total protein, expressed as percent of non-FeCl 3 -treated cells. (e) L6 $1.1 \mathrm{~kb}$ cells were transfected with either a control siRNA (siCo) or specific caspase 3 siRNA (siC3) or (siC6). Fourty hours post-transfection, cells were exposed to $500 \mu \mathrm{M} \mathrm{FeCl}_{3}$, and harvested for luciferase assay to measure NHE1 promoter activity at 12, 18 and $24 \mathrm{~h}$. Expression of caspases 3 and 6 was determined by Western blotting as described in Materials and methods. (f) $\mathrm{L} 61.1 \mathrm{~kb}$ cells were treated with $500 \mu \mathrm{M} \mathrm{FeCl}_{3}$ in $0.5 \% \mathrm{FBS}$ for $24 \mathrm{~h}$. Single-cell suspensions of $\mathrm{L} 61.1 \mathrm{~kb}$ cells were prepared, stained with propidium iodide and analyzed by FACS to quantify the percent of cells with DNA content corresponding to the hypodiploid subG1 phase of the cell cycle. Percent of apoptotic cells was calculated by the percentage of cells in subG1 to the total cells' population. Data from (a-f) represent the average \pm S.D. of two experiments carried out in duplicate 
a

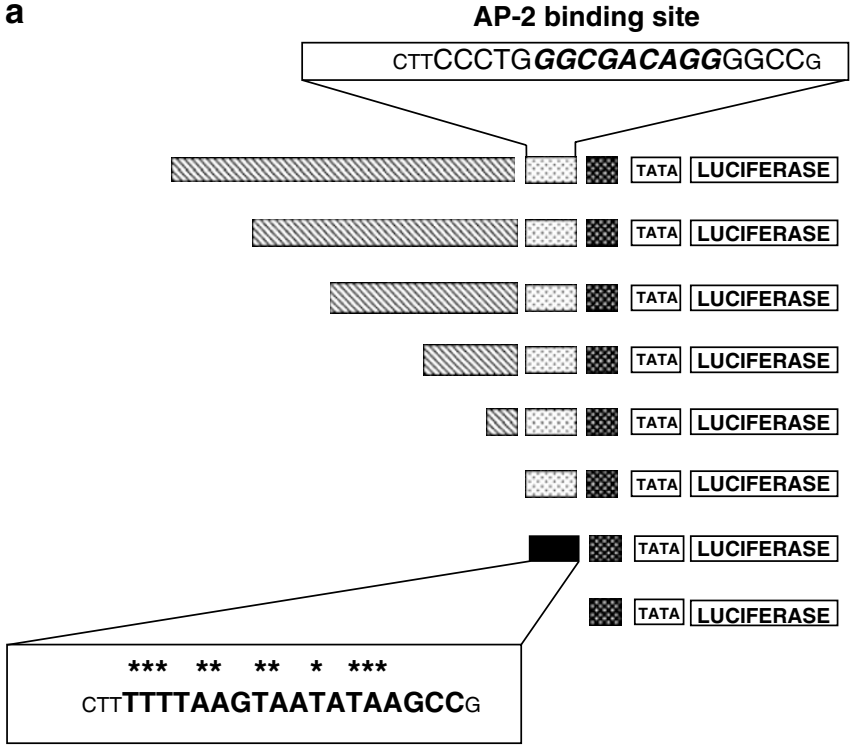

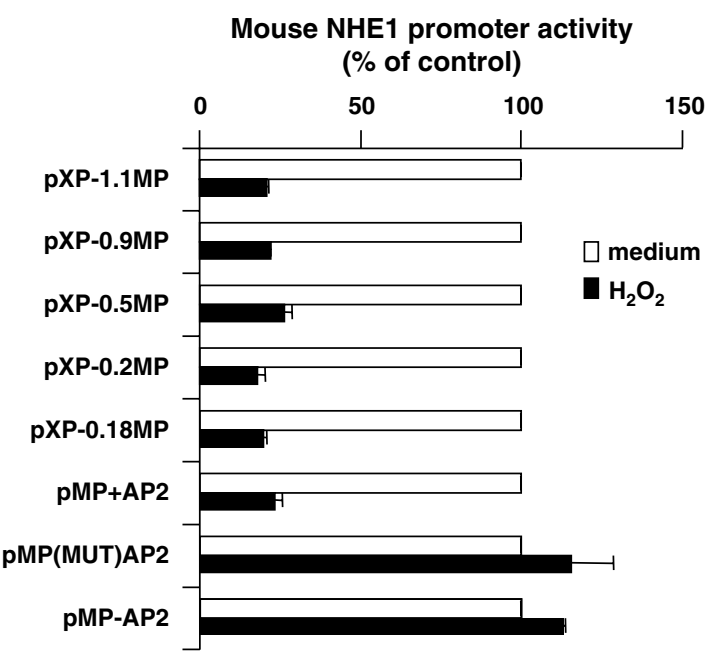

Mutated AP-2 site

b

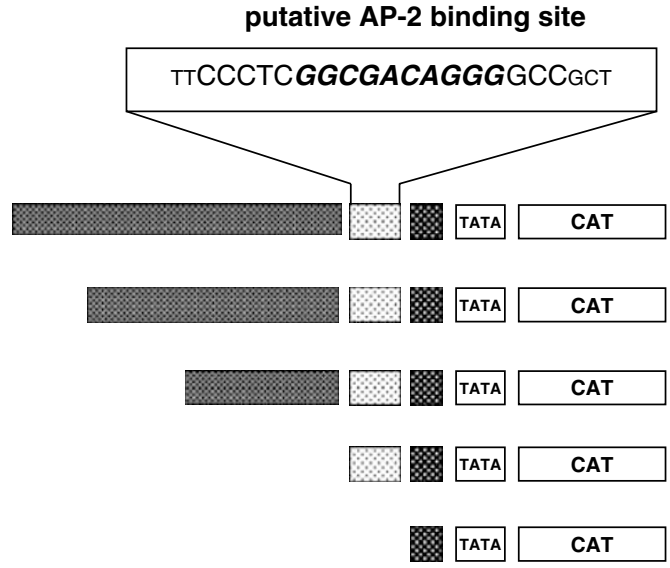

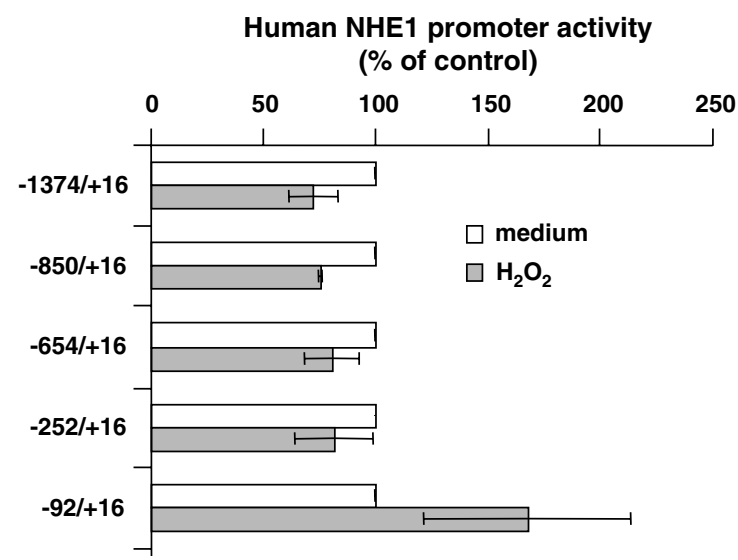

Figure 9 Localization of the $\mathrm{H}_{2} \mathrm{O}_{2}$ Response element. (a) Schematic of the series of $5^{\prime}$ deletion derivatives, and AP2 mutated construct of the mouse NHE1 promoter. The various constructs were transiently transfected into wild-type $\mathrm{L} 6$ cells. Cells were also cotransfected with Renilla plasmid to normalize for transfection efficiency. Promoter activity was then assessed by luciferase activity in the absence and presence of $50 \mu \mathrm{M} \mathrm{H}_{2} \mathrm{O}_{2}$ at $24 \mathrm{~h}$. Promoter activity was calculated as the percentage of control cells $(\%$ of control). The top boxed captitalized sequence indicates the region containing the AP2-binding site within the mouse NHE1 promoter, with the AP2 consensus sequence in italic bold. The bottom boxed bold sequence indicates the mutations made to the AP2 binding site. Asterisks indicate mutated sequences. Data represent the average \pm S.D. of three experiments carried out in duplicate. (b) Schematic representation of the human NHE1 promoter -CAT $5^{\prime}$ deletion mutants. The various constructs were transiently transfected into wild-type L6 cells. Cells were then incubated in the absence and presence of $50 \mu \mathrm{M} \mathrm{H}_{2} \mathrm{O}_{2}$ and harvested at $24 \mathrm{~h}$. Promoter activity assessed by CAT ELISA according to manufacturer's instruction and expressed as percent from non- $\mathrm{H}_{2} \mathrm{O}_{2}$-treated cells. Boxed capitalized sequence indicates the region containing the putative AP2binding site within the human NHE1 promoter by sequence analysis, with the AP2 consensus sequence italicized and bold. Data represent the average \pm S.D. of two experiments done in duplicate

also the caspase-mediated inhibition of the promoter activity. These data indicate that the oxidative signal involved in the rapid inhibition of NHE1 promoter activity is also operative in the induction of caspases 3 and 6 activities following exposure to $\mathrm{H}_{2} \mathrm{O}_{2}$. These data are intriguing given that the concentrations of $\mathrm{H}_{2} \mathrm{O}_{2}$ used throughout this study did not affect cell viability, yet triggered a caspase-dependent repression of NHE1 promoter activity. Furthermore, in the context of apoptotic signaling the activation of caspases 3 and/or 6 is/are usually downstream of initiator caspases such as caspases 8 or 9 , whereas in the present study, physiologically relevant concentrations of $\mathrm{H}_{2} \mathrm{O}_{2}$ failed to induce caspases 8 and/or 9 activities and inhibitors of these caspases did not rescue caspase-dependent inhibition of NHE1 promoter activity by $\mathrm{H}_{2} \mathrm{O}_{2}$. Hence, activation of caspases 3 and 6 in our model occurs independent of initiator caspases 8 and/or 9 .

The activation of caspases 3 and 6 appears to be dependent on the presence of iron. Chelating iron with DFO prevented activation of caspases 3 and 6 , but did not prevent the initial decrease in NHE1 promoter activity following exposure of cells to $\mathrm{H}_{2} \mathrm{O}_{2}$. However, similar to the effect of 
caspase 3 or 6 inhibition, the presence of DFO allowed NHE1 promoter activity to recover to its initial level within $24 \mathrm{~h}$ of exposure to $\mathrm{H}_{2} \mathrm{O}_{2}$. These data demonstrate that the initial uptake of $\mathrm{H}_{2} \mathrm{O}_{2}$ into the cells initiates both a direct, albeit reversible, oxidation-dependent signal, and a response mediated by iron-dependent activation of caspases 3 and 6 . To our knowledge the mechanism of caspase activation by iron is not clearly understood. The closest report on the matter are data reported by Antunes and Cadenas, ${ }^{15}$ demonstrating that physiologically relevant levels of $\mathrm{H}_{2} \mathrm{O}_{2}$ activate apoptotic signaling via a Fenton-type reaction involving iron and the generation of $\mathrm{OH}^{\cdot{ }^{24}}$ Unlike DFO, scavenging $\mathrm{OH}^{\cdot}$ had no effect on $\mathrm{H}_{2} \mathrm{O}_{2}$-induced repression of $\mathrm{NHE} 1$ promoter activity and gene expression. Moreover, the effect of direct addition of $\mathrm{FeCl}_{3}$ on $\mathrm{NHE} 1$ promoter activity and protein expression further provides support on the role of iron in the caspasedependent inhibition of NHE1 promoter activity. This ironmediated inhibition of NHE1 promoter activity was blocked upon gene silencing of caspases 3 or 6 by siRNA, but not by the $\mathrm{OH}^{\prime}$ scavenger $\mathrm{HCOONa}$. The exact mechanism involved in the activation of caspases 3 and 6 by iron is not well understood at the moment.

In conclusion, this is the first report highlighting the role of caspases 3 and 6 in the oxidative repression of gene expression in the absence of initiator caspase activation and cell death. This pathway leading to the repression of NHE1 protein expression by mild oxidative stress may be critical in understanding the long-term effects of oxidative stress on the cells' capacity to proliferate, senesce, age, or undergo transformation. Our data support that the decrease in NHE1 expression by activation of caspase 3 and 6 may be critical in preventing cells growth following a mild oxidative stress, even in the absence of cell death. This results places activation of caspase 3 and 6 by iron as a critical sensor that may decide if cells can grow following mild oxidative stress. Overcoming that sensor may be what is needed to lead to tumorigenesis upon chronic oxidative stress.

\section{Materials and Methods}

Reagents and antibodies. Most of the reagents used were purchased from Sigma-Aldrich, cell culture reagent were purchased from Hyclone, caspase inhibitors from R\&D Systems and antibodies from Chemicon, Cell Signaling, Sigma, DakoCytomation and Pierce. For detail refer to Supplementary data.

Cell culture. Rat muscle cell line, L6 stably transfected with full-length $1.1 \mathrm{~kb}$ of the mouse NHE1 promoter, inserted $5^{\prime}$ to the luciferase reporter gene (designated L6 $1.1 \mathrm{~kb}$ cells) were maintained in Dulbecco's modified Eagle's medium (DMEM) supplemented with $10 \% \mathrm{FBS}, 2 \mathrm{mM}$ L-glutamine, $0.25 \mathrm{mg} / \mathrm{ml}$ geneticin (GIBCO), and $1 \mathrm{mM}$ gentamicin sulfate (BioWhittaker). NIH3T3 cells were maintained in RPMI with 10\% FBS and normal human fibroblasts (IMR90) in MEM supplemented with vitamins, essential and nonessential amino acids.

Caspase activity assay. Caspase activity was assessed as described previously. ${ }^{8}$ For detail see Supplementary data.

Crystal violet assay. Crystal violet assay was performed as described previously. ${ }^{8}$ For detail refer to Supplementary data.

DNA fragmentation assay. DNA fragmentation was performed as described previously. ${ }^{25}$ For detail refer to Supplementary data.

Western blot analysis. Western blot analysis was performed as described previously. ${ }^{8}$ For detail refer to Supplementary data.
Luciferase reporter assay. NHE1 promoter activity was assessed with a single-luciferase assay kit (Promega). Bioluminescence generated was measured using a Sirius luminometer (Berthold). The luminescence readings obtained were normalized to the protein content of the corresponding cell lysate. For detail refer to Supplementary data.

CAT ELISA. The levels of CAT protein were quantified using a CAT antigen capture enzyme-linked immunosorbent assay (ELISA) (Roche Molecular Biochemicals). All CAT quantitations were normalized to the protein concentration of the cell extract, as determined using the Coomasie Plus Protein Assay Reagent Kit (Pierce)

Reporter plasmid constructs. Luciferase reporter plasmid constructs: pXP-1.1MP, pXP-0.9MP, pXP-0.5MP, pXP-0.2MP, pXP-0.18MP, pMP + AP2, pMP-AP2, pMP(MUT)AP2, and empty vector $\mathrm{pXP1}$ were kindly provided by $\mathrm{Dr}$. Larry Fliegel, Department of Biochemistry, University of Alberta, Canada. ${ }^{2}$ pUCSSCAT reporter plasmid constructs: $-1374 /+16,-850 /+16,-654 /+16,-252 /$ $+16,-92 /+16$, and empty vector pUCSS-CAT were kindly provided by Dr. Alexey Kolyada, Department of Medicine, Tufts University School of Medicine, Boston, USA. ${ }^{26}$

DNA transfection. Cells were transfected using CalPhost Mammalian transfection kit (Clonetech). Cotransfection with the Renilla plasmid (Clonetech) was used to assess transfection efficiency in dual-luciferase reporter assay (Promega).

RNA interference for silencing caspases $\mathbf{3}$ and $\mathbf{6}$. SiRNA inhibition of endogenous caspase 3 and 6 was achieved using custom designed siRNA (Ambion). A control siRNA (nonhomologous to any known gene sequence) (Qiagen) was used as a negative control. Cells were transfected with siRNA using the CalPhos Mammalian Transfection kit.

RNA isolation and NHE1 mRNA determination by real-time PCR. Total RNA was isolated from cells by TRIZOL reagent (Invitrogen) as described by manufacturer's instructions with a DNAse treatment step incorporated into the protocol. Each RT reaction contains $2.5 \mu \mathrm{g}$ of total RNA, $1 \times \mathrm{RT}$ buffer, $5 \mathrm{mM} \mathrm{MgCl}, 425 \mu \mathrm{M}$ each of dNTPs, $2 \mu \mathrm{M}$ random hexamers, $0.35 \mathrm{U} / \mu \mathrm{l}$ RNase inhibitor, $1.1 \mathrm{U} / \mu \mathrm{l}$ MultiScribe ${ }^{\mathrm{TM}}$ reverse transcriptase and made up to $10 \mu \mathrm{l}$ with sterile water. RT reaction was carried out at $37^{\circ} \mathrm{C}$ for $1 \mathrm{~h}$. Five microliters of the $10 \mu \mathrm{l}$ CDNA reaction volume was used in real-time quantitative PCR using ABI PRISM 7500 (Applied Biosystems). Normalization was to glyceraldehyde 3-phosphate dehydrogenase (GAPDH) for human RNA and 18S RNA for mouse and rat RNA. Fluorescence was measured with the Sequence Detection Systems 2.0 software. PCR was performed in multiplex (both target and endogenous control co-amplified in the same reaction) with distinct fluorescent dyes. The sequences for primers $(300 \mathrm{nM})$ and probe $(200 \mathrm{nM})$ for mouse NHE1 used in this study are as follows: mouse NHE1, forward ( $5^{\prime}$-TGC CTC ATG AAG ATA GGT TTC CA-3'), reverse $\left(5^{\prime}\right.$ AGC AGC CCC ACT ACG ATC AG-3'), and probe (5'-FAM-CAC CAT CTC AAG CAT CGT CCC GGA-TAMRA- $3^{\prime}$ ). Primers and probe for human GAPDH, rat NHE1, human NHE1, and 18S RNA were purchased as kits from Applied Biosystems (Assays on Demand).

Cell morphology. The morphology of the cells was analyzed using the Olympus digital camera (C4040ZOOM, 4.1 mega pixels) attached to the light microscope (Olympus CK2) at $200 \times$ magnification.

Acknowledgements. We thank Lim Ching Aeng for the preliminary results he generated on the regulation of $\mathrm{NHE} 1$ by $\mathrm{H}_{2} \mathrm{O}_{2}$ during his 2003/2004 final year honors project and Dr Alexey Kolyada, Tufts University, Boston, MA, USA, for the human NHE1 promoter constructs. This work was supported by grant R-183-000130-112 from the Academic Research Fund from the National University of Singapore to MVC, R-364-000-044-112 Academic Research Fund from the National University of Singapore to APK, MVC and SP and the Canadian Institute of Health Research to LF.

1. Pervaiz S, Clement MV (2002) A permissive apoptotic environment: function of a decrease in intracellular superoxide anion and cytosolic acidification. Biochem Biophys Res Commun 290: $1145-1150$ 
2. Pervaiz S, Clement MV (2002) Hydrogen peroxide-induced apoptosis: oxidative or reductive stress? Methods Enzymol 352: 150-159.

3. Clement MV, Stamenkovic I (1996) Superoxide anion is a natural inhibitor of FAS-mediated cell death. EMBO J 15: 216-225

4. Clement MV, Pervaiz S (2001) Intracellular superoxide and hydrogen peroxide concentrations: a critical balance that determines survival or death. Redox Rep 6: 211-214.

5. Pervaiz S, Ramalingam JK, Hirpara JL, Clement MV (1999) Superoxide anion inhibits drug-induced tumor cell death. FEBS Lett 459: 343-348.

6. Pervaiz S, Cao J, Chao OS, Chin YY, Clement MV (2001) Activation of the RacGTPase inhibits apoptosis in human tumor cells. Oncogene 20: 6263-6268.

7. Clement MV, Ponton A, Pervaiz S (1998) Apoptosis induced by hydrogen peroxide is mediated by decreased superoxide anion concentration and reduction of intracellular milieu. FEBS Lett 440: 13-18.

8. Akram S, Teong HF, Fliegel L, Pervaiz S, Clement MV (2006) Reactive oxygen speciesmediated regulation of the $\mathrm{Na}^{+}-\mathrm{H}^{+}$exchanger 1 gene expression connects intracellula redox status with cells' sensitivity to death triggers. Cell Death Differ 13: 628-641.

9. Putney LK, Barber DL (2003) Na-H exchange-dependent increase in intracellular pH times G2/M entry and transition. J Biol Chem 278: 44645-44649.

10. Droge W (2002) Free radicals in the physiological control of cell function. Physiol Rev 82 47-95.

11. Morel $Y$, Barouki R (2000) The repression of nuclear factor I/CCAAT transcription factor (NFI/CTF) transactivating domain by oxidative stress is mediated by a critical cysteine (Cys-427). Biochem J 348 (Part 1): 235-240.

12. Yang W, Dyck JR, Fliegel L (1996) Regulation of NHE1 expression in L6 muscle cells. Biochim Biophys Acta 1306: 107-113.

13. Lamkanfi M, Festjens N, Declercq W, Vanden Berghe T, Vandenabeele P (2007) Caspases in cell survival, proliferation and differentiation. Cell Death Differ 14: 44-55.

14. Wu KL, Khan S, Lakhe-Reddy S, Wang L, Jarad G, Miller RT et al. (2003) Renal tubular epithelial cell apoptosis is associated with caspase cleavage of the NHE1 Na+/H exchanger. Am J Physiol Renal Physiol 284: F829-F839.
15. Antunes F, Cadenas $\mathrm{E}$ (2001) Cellular titration of apoptosis with steady state concentrations of $\mathrm{H}_{2} \mathrm{O}_{2}$ : submicromolar levels of $\mathrm{H}_{2} \mathrm{O}_{2}$ induce apoptosis through Fenton chemistry independent of the cellular thiol state. Free Radic Biol Med 30: 1008-1018.

16. Yang W, Dyck JR, Wang H, Fliegel L (1996) Regulation of NHE-1 promoter in mammalian myocardium. Am J Physiol 270: H259-H266.

17. Dyck JR, Silva NL, Fliegel $L$ (1995) Activation of the $\mathrm{Na}^{+} / \mathrm{H}^{+}$exchanger gene by the transcription factor AP- 2. J Biol Chem 270: 1375-1381.

18. Eckert D, Buhl S, Weber S, Jager R, Schorle H (2005) The AP-2 family of transcription factors. Genome Biol 6: 246.

19. Huang Y, Domann FE (1998) Redox modulation of AP-2 DNA binding activity in vitro. Biochem Biophys Res Commun 249: 307-312.

20. Thornberry NA (1998) Caspases: key mediators of apoptosis. Chem Biol 5: 97-103.

21. Chang J, Wei L, Otani T, Youker KA, Entman ML, Schwartz RJ (2003) Inhibitory cardiac transcription factor, SRF-N, is generated by caspase 3 cleavage in human heart failure and attenuated by ventricular unloading. Circulation 108: 407-413.

22. De Maria R, Zeuner A, Eramo A, Domenichelli C, Bonci D, Grignani F et al. (1999) Negative regulation of erythropoiesis by caspase-mediated cleavage of GATA-1. Nature 401 . 489-493.

23. Nyormoi O, Wang Z, Doan D, Ruiz M, McConkey D, Bar-Eli M (2001) Transcription facto AP-2alpha is preferentially cleaved by caspase 6 and degraded by proteasome during tumor necrosis factor alpha-induced apoptosis in breast cancer cells. Mol Cell Biol 21 $4856-4867$.

24. Antunes F, Cadenas E, Brunk UT (2001) Apoptosis induced by exposure to a low steady-state concentration of $\mathrm{H} 2 \mathrm{O} 2$ is a consequence of lysosomal rupture. Biochem $J$ 356: 549-555.

25. Chao OS, Clement MV (2006) Epidermal growth factor and serum activate distinct pathways to inhibit the $\mathrm{BH} 3$ only protein $\mathrm{BAD}$ in prostate carcinoma LNCaP cells. Oncogene 25: 4458-4469.

26. Kolyada AY, Lebedeva TV, Johns CA, Madias NE (1994) Proximal regulatory elements and nuclear activities required for transcription of the human $\mathrm{Na}^{+} / \mathrm{H}^{+}$exchanger (NHE-1) gene. Biochim Biophys Acta 1217: 54-64.

\section{Supplementary Information accompanies the paper on Cell Death and Differentiation website (http://www.nature.com/cdd)}

